\title{
The Empirical Analysis Model on Identifying Sick Building Syndrome in Hot Humid Tropical Buildings
}

\author{
Nurrahmi Kartikawati ${ }^{1}$, Erni Setyowati ${ }^{2, *}$, Djoko Indrosaptono ${ }^{2}$ \\ ${ }^{1}$ Doctoral Program of Architecture and Urbanism, Engineering Faculty of Diponegoro University, Semarang, 50275, Indonesia \\ ${ }^{2}$ Department of Architecture, Engineering Faculty of Diponegoro University, Semarang, 50275, Indonesia
}

Received November 9, 2020; Revised December 22, 2020; Accepted January 20, 2021

\section{Cite This Paper in the following Citation Styles}

(a): [1] Nurrahmi Kartikawati, Erni Setyowati, Djoko Indrosaptono, "The Empirical Analysis Model on Identifying Sick Building Syndrome in Hot Humid Tropical Buildings," Civil Engineering and Architecture, Vol. 9, No. 1, pp. 52 - 73, 2021. DOI: 10.13189/cea.2021.090105.

(b): Nurrahmi Kartikawati, Erni Setyowati, Djoko Indrosaptono (2021). The Empirical Analysis Model on Identifying Sick Building Syndrome in Hot Humid Tropical Buildings. Civil Engineering and Architecture, 9(1), 52 - 73. DOI: 10.13189/cea.2021.090105.

Copyright $@ 2021$ by authors, all rights reserved. Authors agree that this article remains permanently open access under the terms of the Creative Commons Attribution License 4.0 International License

\begin{abstract}
A tropical hot humid climate provides high humidity that influences the occupant's comfort. This study highlights a comparison of physical measurements and perceptions related to thermal comfort, indoor air quality, and sick building syndrome (SBS) in tropical humid climate buildings. The research method used ASHRAE 2017 and analysis using SPSS 24 by two analytical models, i.e., Model 1 and Model 2. The Model 1 included measurement data of independent variables T, RH, $\mathrm{V}$, and $\mathrm{CO}_{2}$, and SBS dependent variable, while the Model 2 used perception data of independent variables T, RH, V, and QA, and SBS dependent variable. The study found the conditions were unsuitable with ASHRAE 2017, however, the new SBS index model for the hot-humid tropic has been established. The average temperature was 29.4-31. $3^{\circ} \mathrm{C}$, the perception of 'neutral' was responded by $50.6 \%$ of all respondents, $36.7 \%$ stated 'warm' and $7.6 \%$ stated 'hot'. The average relative humidity was between $77-82.4 \%$, but about $50.6 \%$ of respondents declared 'neutral', only $8.9 \%$ declared 'slightly damp', and 2.5\% stated 'damp'. The test results showed Model 2 performed the cyclical effect on SBS, in contrast, Model 1 had no significant effect on SBS because of the varied adaptation of occupants.
\end{abstract}

Keywords Hot Humid Tropical Buildings, Thermal Comfort, Indoor Air Quality, Sick Building Syndrome

\section{Introduction}

One of the remarkable things in occupancy is the indoor comfort aspect and the occupant's health. The comfort and health of the residents are inseparable from thermal conditions and indoor air quality. Thermal comfort condition is determined by climatic aspects, such as in Indonesia, which has a hot humid tropical climate. As the main character of the humid tropical climate is high rainfall, high humidity, and warm to hot temperatures becomes the influential factors for indoor thermal comfort. Building with high moisture and warm temperatures can be a habitat for fungus and other microorganisms that can interfere with occupant's health [1]. On the other side, air pollutants coming from inside and outside the building affect the air quality in the building. Air quality degradation brings a notable impact on human health. Approximately 4-5 million people passed away due to air pollutions in 2017 [2]. In contrast, a good air quality takes part in effective healing for some patients that are too sensitive to air pollutants [3]. Particulate matter PM 2.5 is considered as the most remarkable factor to influence the air quality index for more than 90\% [4]. The particle of PM 2.5 is associated with vehicle and traffic emission [4]. Due to the vast effect of air quality, providing a pure air policy and implementation plan is necessary, especially for areas with high air pollution [5].

During this pandemic, the environmental hygiene aspects of both outdoor and indoor become important. The 
study looked at the influence of both indoor air quality and the health of building users. In public housing such as student dormitories, the comfort aspect is complicated because it involves not only one individual but also the other occupant. Therefore, personal comfort perception is remarkable in determining the comfort of the rooms. On the other hand, physical aspects such as temperature, humidity, and wind speed are measurable. The differences in perception and measurement outcome can occur in studies using the two methods. The thermal comfort perception of the resident presents by the PMV (Predicted Mean Vote), which ranges from -3 to +3 [6]. The perception assessment in this study adopted PMV values with a range of 'very cold' to 'very hot' with adjustments according to the study's needs [6]. The indoor thermal comfort conditions can be affected by climate and architectural factors, while the temperature and air circulation of the room can be affected by outdoor climatic conditions [7]. Architectural aspects such as glass walls can significantly increase room temperature when the buildings are exposed to solar radiation, which the rising room temperature leads to SBS risk [8]. In line with the previous statement, the high transparency ratio, which can be found in a large glass windows, results in overheating and uncomfort sensation [9]. It indicates the thermal transmittance of the building envelope material which is known as $\mathrm{U}$ value, plays a remarkable role in thermal comfort, which may correlate to SBS. The high U value means a large amount of heat transfer through the structure cover substance. The building with high $\mathrm{U}$ value tends to be more risky on SBS [10].

On the other side, the interconnectedness of the air circulation of indoor and outdoor can affect sick building syndrome (SBS) risk. If the air circulation of indoor and outdoor runs smoothly, the risk of SBS may decrease $[8,11]$. Sick building syndrome risk can also occur in rooms with too cold temperatures and poor ventilation [12]. The difference in topography conditions affects the perception of thermal comfort of the occupants. In the rural areas of the mountains, residents have a lower comfortable temperature than residents in urban areas [13]. Therefore, there is a suspected difference in thermal satisfaction results in the two buildings with different topography.

Good air quality, among others, is determined by low carbon emissions. The high carbon emissions trigger global warming, making it is necessary to develop low-carbon residential designs [14]. Pollutants often found indoors include volatile organic compounds (VOC) such as formaldehyde from the new furniture and decorations [15]. The existence of formaldehyde in indoor air should not be more than $0.081 \mathrm{ppm}$ for about 30 minutes, based on the WHO standard [16]. Besides, according to ASHRAE 2017, benzene is also a VOC group that exists indoors [16]. Referring to the WHO, the presence of benzene should be as low as possible [16].
The sources of VOCs among others are cleaning products and personal care products [16]. Another pollutant such as $\mathrm{CO}_{2}$ is residual combustion of motor vehicles and industrial activities [16]. A significant carbon footprint detection in dense settlements of urban environments is a residual daily citizen activity, such as meeting the needs of clean water and electricity [14]. The $\mathrm{CO}_{2}$ tolerated level in non-industrial environments reaches around 1000 $\mathrm{ppm}$, more than that, $\mathrm{CO}_{2}$ results in short-breath or shortness of breath effects $[16,17]$. In a residential area, $\mathrm{CO}_{2}$ level is considered reasonable at $660 \mathrm{ppm}$ [18].

Droplets release into the air and inhaled by other building users can carry viruses and bacteria away. As the study of SARS transmission in Hong Kong occurred through droplets of airborne sufferers [16], as well as Covid-19 spreads through inhalled droplets [19], there is no escape from the current issue, where both the SARS and Covid-19 pandemic are considered as strongly transmitted through droplets released into the air. Other study found a high association of infections among students with low ventilation levels $[16,20]$. In addition, both of infection and allergy can also be triggered by air conditions in buildings containing allergens [21]. Indoor air circulation plays an important role in thermal comfort and indoor health. According to ASHRAE, 2017 [16], indoor air circulation should be about $0.2 \mathrm{~m} / \mathrm{s}$ for thermal comfort and at least $0.3 \mathrm{~m} / \mathrm{s}$ to maintain indoor air free from pollutants. The ventilation function is more effective in a high ceiling room than in a low ceiling room [22]. Low ventilation levels accompanied by VOC, formaldehyde, PM 2.5, and other fine particles in the indoor air are associated with the appearance of symptoms of sick building syndrome in residential [23]. Low ventilation levels are associated with irritation of the mucous membrane, the presence of dust, and other fine particles associated with irritation of the mucosa and skin [12]. Indoor air pollutant as particle such as PM 2.5 can be reduced by adequate indoor air movement. PM 2.5 rate limit allows around $12-15 \mu \mathrm{g} / \mathrm{m}^{3}$ in the duration of a year, while within a period of 24 hours, the PM 2.5 value that is still tolerated is $35 \mu \mathrm{g} / \mathrm{m}^{3}$ [16]. Therefore, indoor air circulation is important to keep the indoor air clean.

The condition of indoor air quality determines the risk of sick building syndrome. Both eye-related SBS disorders and decreased short-term performances are associated with low relatively humidity and high $\mathrm{CO}_{2}$ concentrations [24]. In addition, high $\mathrm{CO}_{2}$ levels can exacerbate SBS symptoms indoors with poor ventilation systems [25]. Accumulation of air pollutants with thermal conditions that do not meet standards can cause physical complaints. A high mix of $\mathrm{CO}_{2}$ and VOC levels along with high humidity and warm room temperature can trigger sick building syndrome [26]. Indoor temperature standard is about $21-24^{\circ} \mathrm{C}$, meanwhile, the ideal relative humidity inside the building is not exceed $60 \%$ [16]. In other words, aspects of air quality and thermal comfort are 
related to the health of occupants. Indications of sick building syndrome are known through the symptoms experienced by residents. SBS symptoms are divided into three types, among others [11]: (a) General SBS symptoms: fatigue, headache, dizziness, and difficulty in concentration; (b) Mucous Membrane Symptoms: coughing, sore throat, nasal irritation, and eye irritation; (c) Skin-related Symptoms: dry skin on the face, itchy ear, and dry hand [11].

Generally, people adjust to gain the preferable comfort and reduce psychological tension due to the unstandarized indoor comfort [16]. Differences in perception and comfort preferences cause adaptive behavior patterns to vary between individuals such as window openings, which then affect the energy consumption of buildings [27]. On the other hand, residents have a tolerance to thermal comfort conditions, so new adaptation behaviors will be performed when thermal perception is 'warm' or 'hot' [28]. Similar tolerances occur among the elderly, in which thermal comfort preference in winter turns out to be lower than PMV standards [29]. This indicates the presence of tolerance and variation of the adaptive response of occupants to achieve thermal comfort of the room. The prediction of favored temperature can be approached by adaptive models to gain preferable temperature [16]. Nevertheless, the research boundary does not include preferable temperature as its research aim. This study outlines possible differences in personal perceptions and measurable physical aspects in the context of indoor thermal comfort and indoor air quality. Both aspects are independent variables that are considered to influence sick building syndrome. With this analysis, it is expected that a more significant research model can be determined.

\section{Materials and Methods}

\subsection{Method}

The selection of methods in this study generally refers to the mixed-method of Creswell and the convergent parallel mixed-method [30], which can be seen in Figure 1. In this study, field measurement data represents quantitative and perception data performs qualitative data. In data processing, perception data displays quantitatively to make it easier to analyze alongside other data. The data analysis process is by comparing two types of qualitative and quantitative data. In this case, the data compared are the result of thermal measurements and air quality and perception of thermal comfort and air quality in effect to the risk of sick building syndrome (SBS). In addition to referring to Creswell [30], the method in this study also uses the principle of architectural research methods from Groat and Wang [31], which is generally almost the same as Creswell's method but specific to architectural research. The combination methods, among others, are in the form of research plans covering: (a) A two-phase strategy; (b) A dominant-less dominant strategy; (c) Mixed methodology design [31].

In determining the minimum number of respondents' samples to find out indications of sick building syndrome, clinical sample calculation methods are used [32,33]. According to both references [32,33], the number of samples in the estimated proportions and average comparisons differ from each other. In other words, the number of samples in each type of analysis is different, according to the results of the previous analysis [32,33]. The research determines an indication of sick building syndrome uses the analysis of the estimated proportions and average comparisons of two independent groups [32,33]. The number of comfort perception sample follows the calculation of the sample in general [34]. The provision samples refer to the source in multivariate research, in which the respondents are at least ten times the number of variables [34]. If the sample is divided into several categories, then the number of samples per category is at least 30 [34]. In a more practical stage, the paradigm of the combination method is spelled out through research steps and survey methods such as (a). perception survey; (b). Building (dwelling) assessment; (c) analysis; (d) result and (e). Conclusion [6]. 


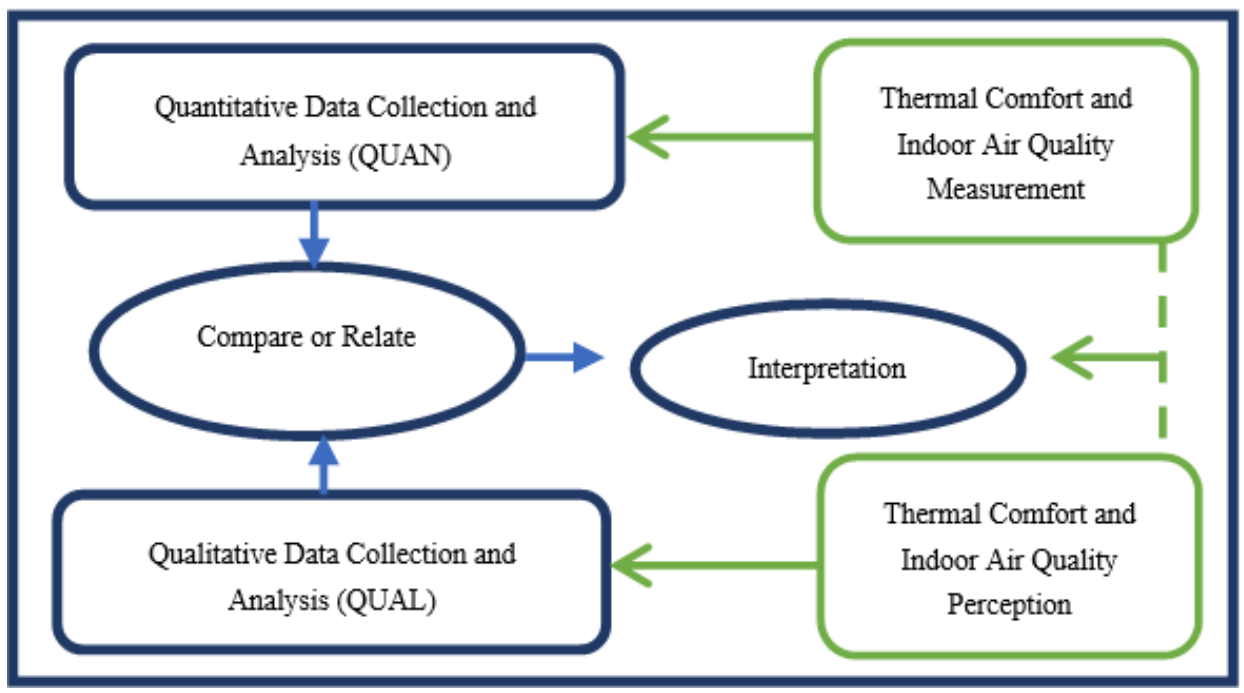

Figure 1. Research Method

\subsection{Location}

The research location conducts in Building $\mathrm{A}$ is a student dormitory in an urban area, which is a lowland area and close to the main road. Building A campus has good landscaping and infrastructure (see Figure 2). Even though it locates in the downtown area, the trees and parks in the campus area are well maintained. The dormitory is among other buildings as an integrated laboratory for medicine, Medicine Faculty, Mosque, and other public facilities. There are two sports fields near the dormitory and a food court. The dormitory building is a single mass shape with skylights on its roof, and air ventilation on each corridor ends. The location and situation of Building A are presented in Figure. 2.

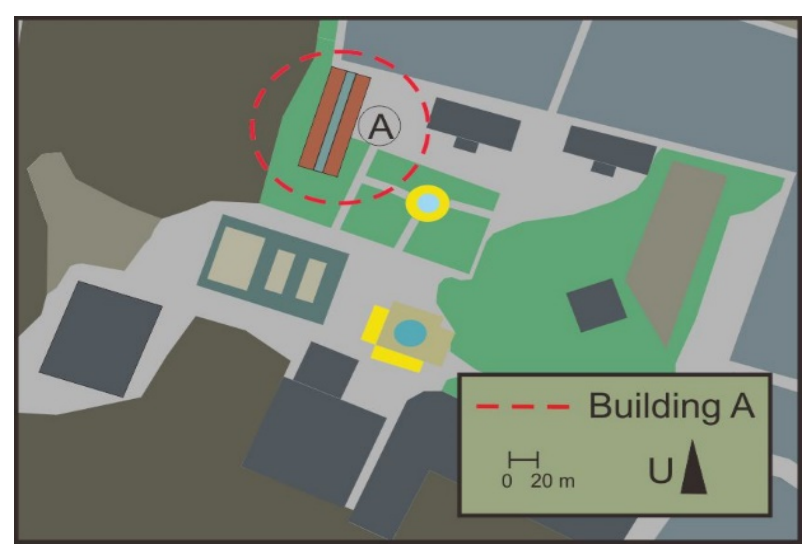

Figure 2. Location of Building A

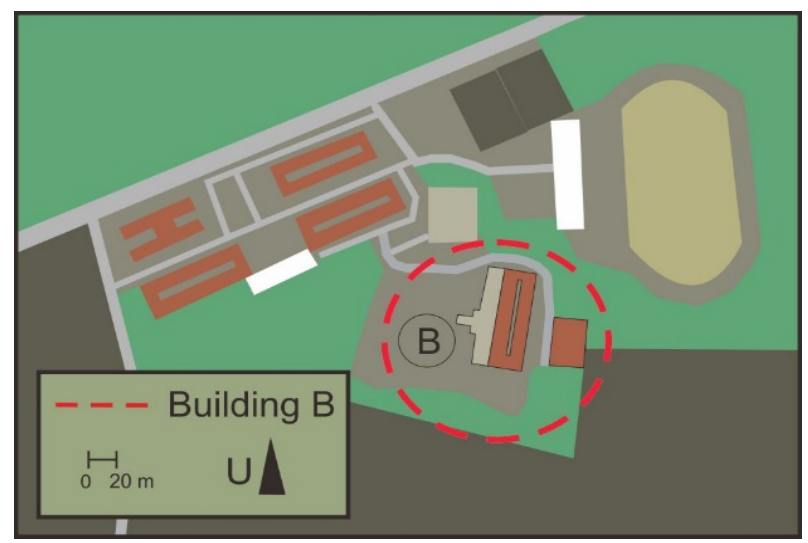

Figure 3. Location of Building $B$

The second location is Building $B$, which is one of the buildings in the student apartment complex (see Figure 3). Figure 3 shows the location and situation of Building B. This student apartment area is located on the campus area and consists of five building units as one of the buildings is being taken as the locus of this research. The location of building $\mathrm{B}$ is on plateau topography in a well-landscaped campus. The area is specifically for student apartments consisted of five towers. Building B is one of the newest buildings in the cluster.

Building B is located in the campus area that near to the preservation areas such as the river and oviduct. The road towards the building is relatively empty because the area belongs to the university. There are some public facilities around the dormitories for the example tennis court, sports stadium, and archery field. 


\subsection{Thermal Comfort and Indoor Air Quality Measurement}

The environmental assessment stage is a measurement of the parameters of thermal comfort and air quality. Several parameters are measured, among others covering: temperature, wind speed, relative humidity, $\mathrm{CO}_{2}$ content, and PM 2.5 as well as TVOC. The air quality parameters are chosen according to some references that highlight some pollutants such as $\mathrm{CO}_{2}$, TVOC, and PM 2.5 as the remarkable factors of indoor air quality [23-26]. The parameter of indoor thermal comfort excluded mean radiant temperature, due to its early concept of indoor thermal comfort took place inside the building which the locations of measurement are shady. Temperature is adequate to predict mean radiant temperature in a radiant cooled indoor environment, in other words, the difference of mean radiant temperature and temperature is negligible in an indoor shaded place [35]. In addition, the research boundary is a comparison between measurement and perception of indoor comfort which each of the measurement parameters is parallel with the perception.

Figure 4 shows typical units of Building A which has a four-story dormitory with a tile roof and a transparent skylight in the middle. There are 25 rooms on floors 2-4 with a size of $4 \times 5$ square meters and on the ground floor as public facilities. Facilities on the ground floor include a canteen, management room, computer room, clinic, and linen room. The main stairs are in the middle of the building, and side stairs are at either end of the building. Shared-bathrooms locate at either end of the building on each floor. The center of the building has two voids that separate the rows of rooms on either side. The width of the corridor in front of the room is about 1.5 meters. The walls of the whole building are light white and cream-colored. The window is $1.2 \times 1.5 \mathrm{~m}$, half of which is a lattice and has a shading width of about $0.5 \mathrm{~m}$.

As can be seen in Figure 5, Building B is a five-story dormitory with a tile roof and voids in the center. The dormitory walls are striking pink and red. The window is about $1.5 \times 1.5 \mathrm{~m}$ and shading about 0.5 meters wide, while the end of the building is a drying room with iron grid walls on each floor. The main staircase is in the middle of the building, while the other stairs are at the ends of the corridors. There is an inner court in the center of the building with voids and open roofs above it. The ground floor has functioned as a public facility, such as living rooms, prayer rooms, toilets, and warehouses. There are 12 rooms on the ground floor and the 2nd -5th floor consists of 24 rooms on each floor. Every room has $3 \times 4$ square meters and a corridor width of about $1.5 \mathrm{~m}$. 


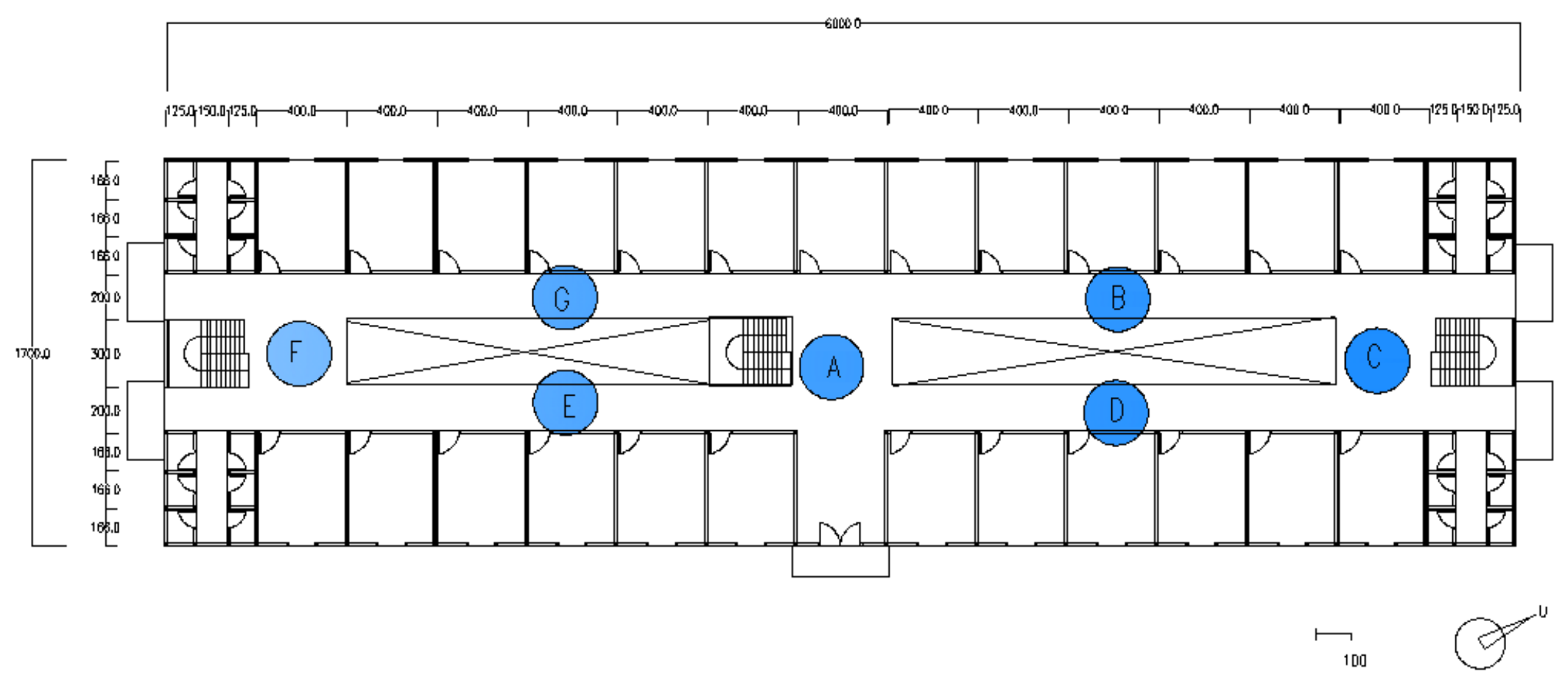

Figure 4. Typical Unit of Building A and Location of Measurement 


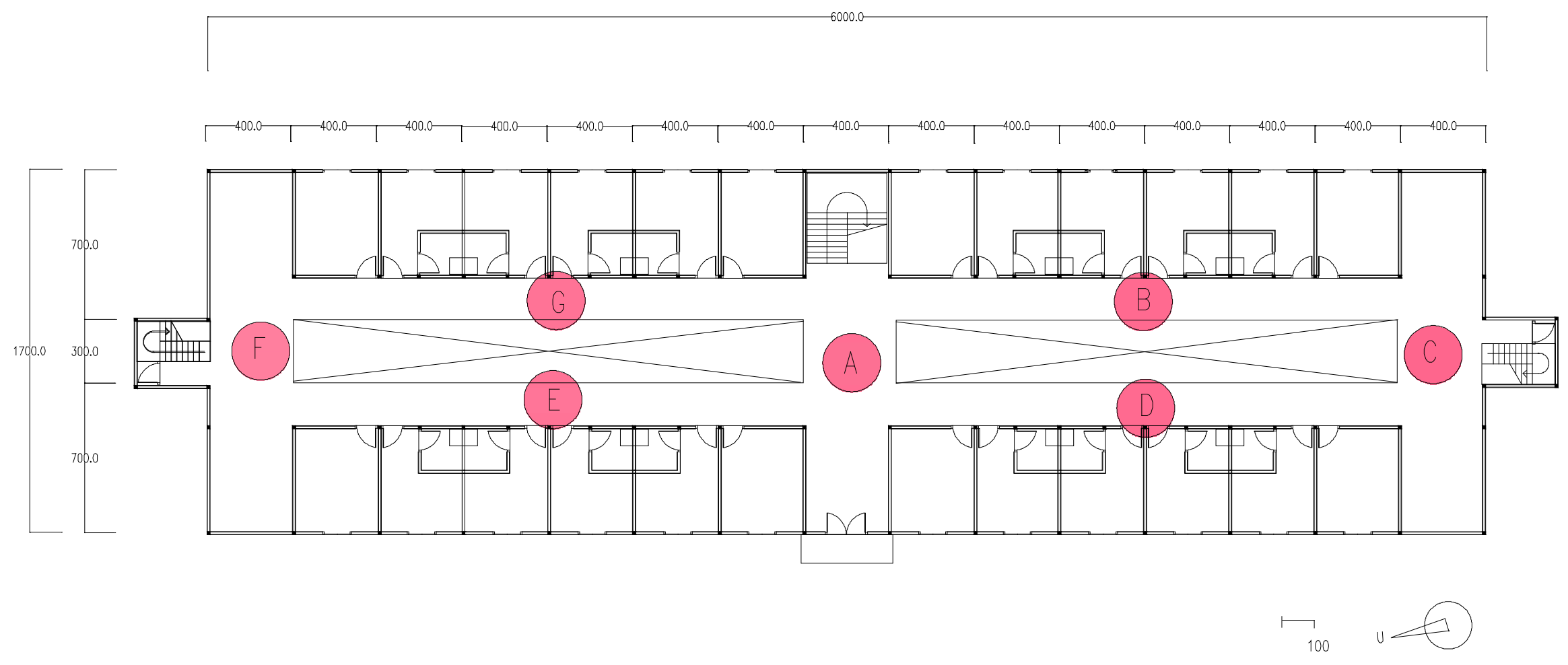

Figure 5. Typical Unit of Building B and Location of Measurement 
Figures. 4 and 5 show the location for measuring thermal and air quality parameters. Measurements of thermal comfort and air quality are carried out for five consecutive days, recording every three hours for 12 hours at the time of occupants were active. Times of recording are at $07.00,10.00,13.00,16.00$, and 19.00. During the times, the tools measure at several points on each floor. The measurement results were analyzed to produce an average value for each parameter on each floor of the building.

\subsection{Perception Survey}

The research conducted the perception survey by compiling an online questionnaire and distributed it to respondents randomly. The questionnaire questions cover the perception of several determinants of thermal comfort such as temperature, humidity, and wind speed, assessed from a personal point of view. Thermal perception questions refer to question types with the following comfort levels: very cold; cold; neutral; enough; hot/warm; very hot; which presents in a rating scale [6]. The questionnaire technique examines the thermal comfort of housing in an urban environment. Indoor air quality perception was expressed by identifying the smell and freshness of the air. The human sense can detect the presence of several pollutants by smell. The unpleasant odor such as burning residues or strong aroma indicates the existence of the pollutant in the room, such as PM 2.5 and TVOCs [16]. The freshness of the air presents on a scale of 1 to 5 . A score of 1 is the lowest, and a score of 5 is the maximum.

The sample size of respondents with the perception of thermal comfort and air quality is determined to be at least 60 people [34]. This sample determination is for the type of research sample in general. The respondents in this perception questionnaire are 79 people from both buildings $\mathrm{A}$ and $\mathrm{B}$. The thermal and indoor air quality measurements took place in the indoor public areas such as corridors and halls, therefore, thermal and indoor air quality perception surveys were about the same places. The questionnaires of indoor comfort perception that were used in this study were about indoor public space

\subsection{Sick Building Syndrome Indication}

The research carried out the indications of sick building syndrome by an online questionnaire. The question in this section covers things that have been experienced by the occupants, related to their comfort condition and temporary physical symptoms. Respondents' answer was analyzed by the scoring of sick building syndrome indication. The distribution of the questionnaires was carried out in February-April 2020, considering the rainfall was high. The estimated peak of the rainy season was in February-March 2020. Respondents of Buildings A and B were 79 randomly selected occupants. Types of clinical analysis used include estimating the proportion and comparison of the means of the two independent groups [32,33]. In this research, after calculation according to references[32,33], the sample for proportion estimation is at least 24 subjects, while the mean comparison of the two independent groups is at least 20 subjects.

\subsection{Data Analysis}

Statistical analysis was conducted by way of comparing two analysis models. The first model uses physical measurement results that are parallel to perception. The second model consists of the variables of thermal comfort and air quality according to respondents' perceptions, which are considered an influence on the indication of sick building syndrome. The analysis performed on each model is a classic assumption test to determine which model 1 or 2 is more influential [36].

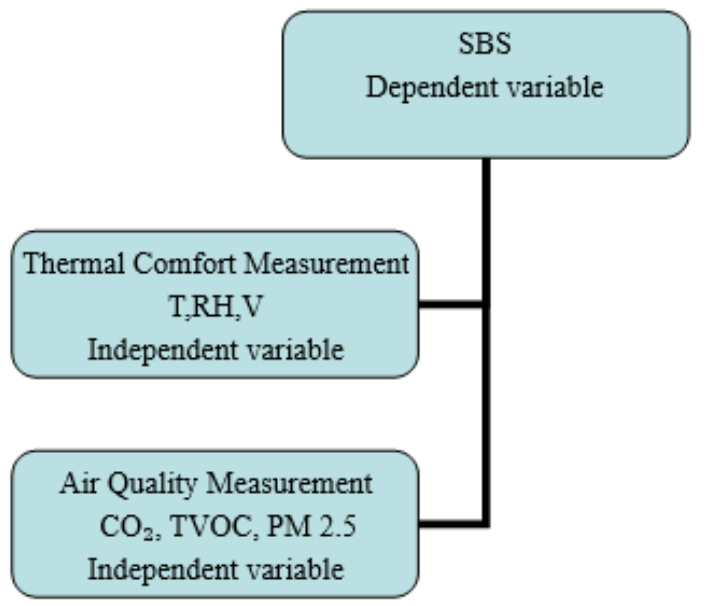

Figure 6. Analysis Scheme of Model 1

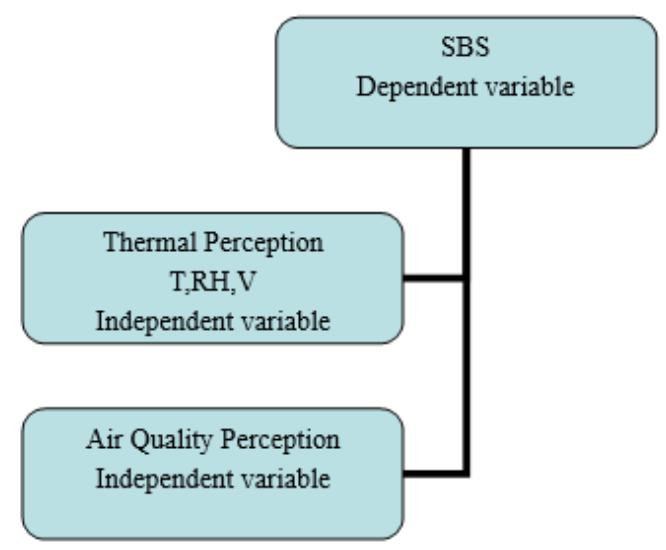

Figure 7. Analysis Scheme of Model 2

The schematic of Model 1 can be seen in Figure 6, which consists of physical measurement output of independent variables in the form of thermal comfort ( $\mathrm{T}$, $\mathrm{RH}, \mathrm{V})$, and indoor air quality $\left(\mathrm{CO}_{2}, \mathrm{PM} 2.5\right.$, and TVOC). 
The dependent variable of Model 1 is the sick building syndrome (SBS) index. With the variables, a classical assumption test is carried out to determine the effect of the independent variable on the dependent variable [34,36]. (see Figure. 6).

Figure. 7 shows a Model 2 schematic using thermal and air quality perception as independent variables. The dependent variable in Model 2 is the sick building syndrome (SBS) index, which is obtained from a questionnaire scoring related to SBS. The data are analyzed using the classical assumption test to determine how significant the effect of the independent variable on the dependent variable is. Analysis in Models 1 and 2 and other analyses use SPSS 24 software [36]. The results of the analysis are compared with the results of the test from Models 1 and 2.

\subsection{Respondents}

There are 79 respondents consisting of 44 people from Building A and 35 from Building B who participated in the study who are all active as students. In general, from the type of activity, all respondents have almost the same type. On the other hand, there are different types of hostel management, which give different characters to daily activities in the residential. Building A has a modern type of boarding school dormitory management, while
Building B is managed as a general student flat. In terms of age, respondents in Building A were first-year students aged 18-19 years. Respondents in Building $B$ have a more varied age level, around 18-22 years. The existence of restrictions on the length of stay is the cause of the homogeneous age level in Building A. On the other hand, there is no regulation limiting the length of stay in Building B.

\section{Result and Discussion}

\subsection{Thermal Comfort and Indoor Air Quality Measurement}

The thermal comfort and indoor air quality are measured by some parameters covering: $\mathrm{T}$ is the temperature in units of ${ }^{\circ} \mathrm{C}$; $\mathrm{RH}$ means Relative Humidity in units of \%; $\mathrm{V}$ is air velocity in units of $\mathrm{m} / \mathrm{s}$; then $\mathrm{CO}_{2}$ is carbon dioxide in units of ppm; then PM 2.5 is particle matter 2.5 in units of $\mu \mathrm{g} / \mathrm{m}^{3}$; while TVOC is Total Volatile Organic Compound in units of ppm. Considering the comfortability, the thermal comfort is presented by temperature $(\mathrm{T})$, relative humidity $(\mathrm{RH})$, and air velocity (V), meanwhile, indoor air quality is measured by $\mathrm{CO}_{2}$ (ppm), PM $2.5\left(\mu \mathrm{g} / \mathrm{m}^{3}\right)$, and TVOC (ppm).

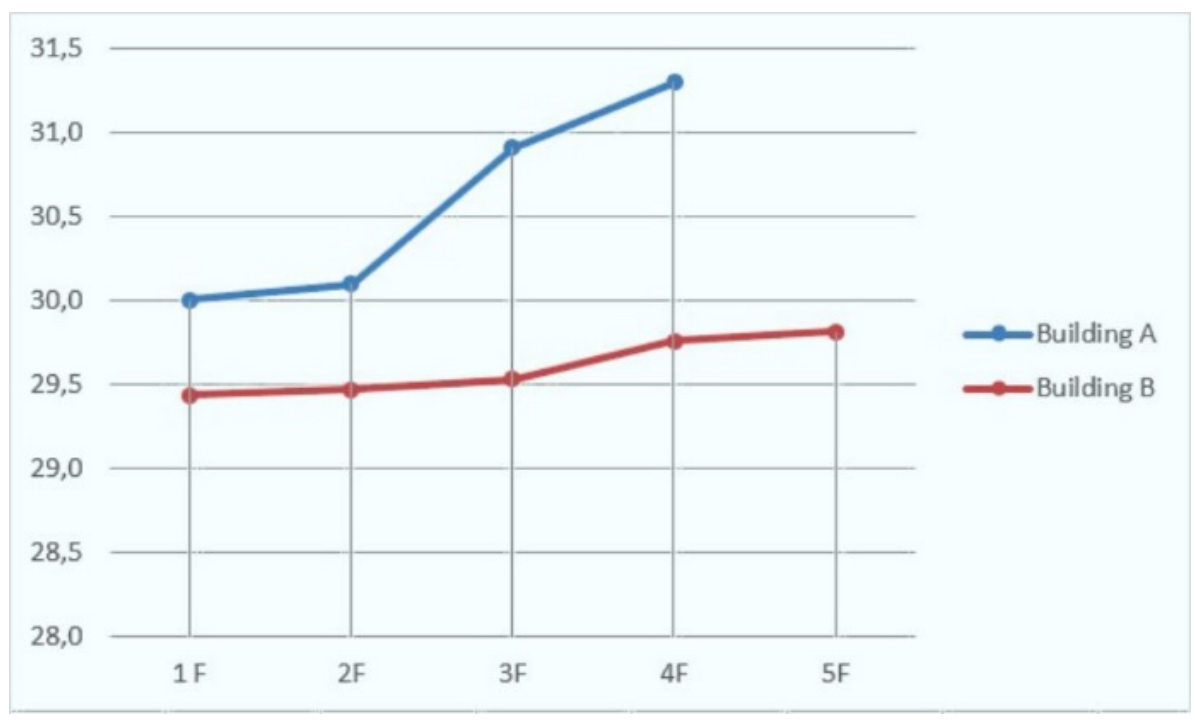

Figure 8. Daily Average Temperature $\left({ }^{\circ} \mathrm{C}\right)$ of Building A and B 
Figure 8 shows the average daily temperature in Building A and B during five days of measurement. The fourth floor of Building $A$ had the highest average temperature of all $\left(31.3^{\circ} \mathrm{C}\right)$. The lowest temperature of Building A is shown on the first floor $\left(30^{\circ} \mathrm{C}\right)$. (See Figure. 8). Meanwhile, the lowest temperature value of all is indicated by the first floor of Building $\mathrm{B}\left(29.4^{\circ} \mathrm{C}\right)$. In contrast, the highest temperature value of Building $B$ is indicated on the fifth floor $\left(29.8^{\circ} \mathrm{C}\right)$. According to ASHRAE 2017, the average temperatures of both buildings are not in line with the standard [16]. The average temperature of Building $\mathrm{A}$ is higher than Building $\mathrm{B}$ due to the roof type of Building A has two side skylight covered by a transparent material. It allows sun radiation through the skylight into the building and increases the indoor temperature. It is suitable with some references which state the transparent surface leads to overheating [8,9], besides, the overheated room improves SBS risk [8]. On the other side, the SBS risk may correlate with U value of the building envelope. The $U$ value as a heat transmittance factor of the materials plays an important role in transfer the heat into the building. The heat transfer can occur through the building envelope such as roof, wall, and window. As the $U$ value is getting higher, the SBS risk improves [10]. It indicates the material of the building envelope influences SBS risk.

Following the data of average temperature, Figure. 9 presents the average of relative humidity for 5 days measurement. The average daily relative humidity of Building A and B can be seen in Figure. 9. The relative humidity (RH) values were over $81 \%$, especially at Building B. The humidity fluctuated around $77-78,7 \%$ at Building A. The highest RH score occurred on the third floor of Building B (82.4\%) followed by the first floor of the same building (81.8\%). In Figure 9., both buildings A and B have RH values exceeding $81 \%$. The lowest RH score is on the first floor of Building A, which RH is approaching $77 \%$. As can be seen in Figure. 9, Building B a has a higher RH value than Building A. According to ASHRAE 2017, the ideal RH is about $40 \%-60 \%$ which means, both buildings A and B RH are unsuitable with the standard. It indicates the thermal comforts in both buildings are not good enough according to ASHRAE 2017.

Furthermore, the average wind speed of Building A and $B$ can be seen in Figure. 10. The air movement is influenced by the weather and building ventilation system, which allowed the air exchanges into and outside the room. Almost all locations of Building A have minimum air movement of about $0 \mathrm{~m} / \mathrm{s}$. Wind speeds in Building A appear small, with average wind speeds only about 0-0.1 $\mathrm{m} / \mathrm{s}$ (see Figure. 10). This condition is not suitable with the ASHRAE standard for air circulation. In contrast, Building B shows good air circulation with winds between $0.4-1,1 \mathrm{~m} / \mathrm{s}$ (see Figure. 10).

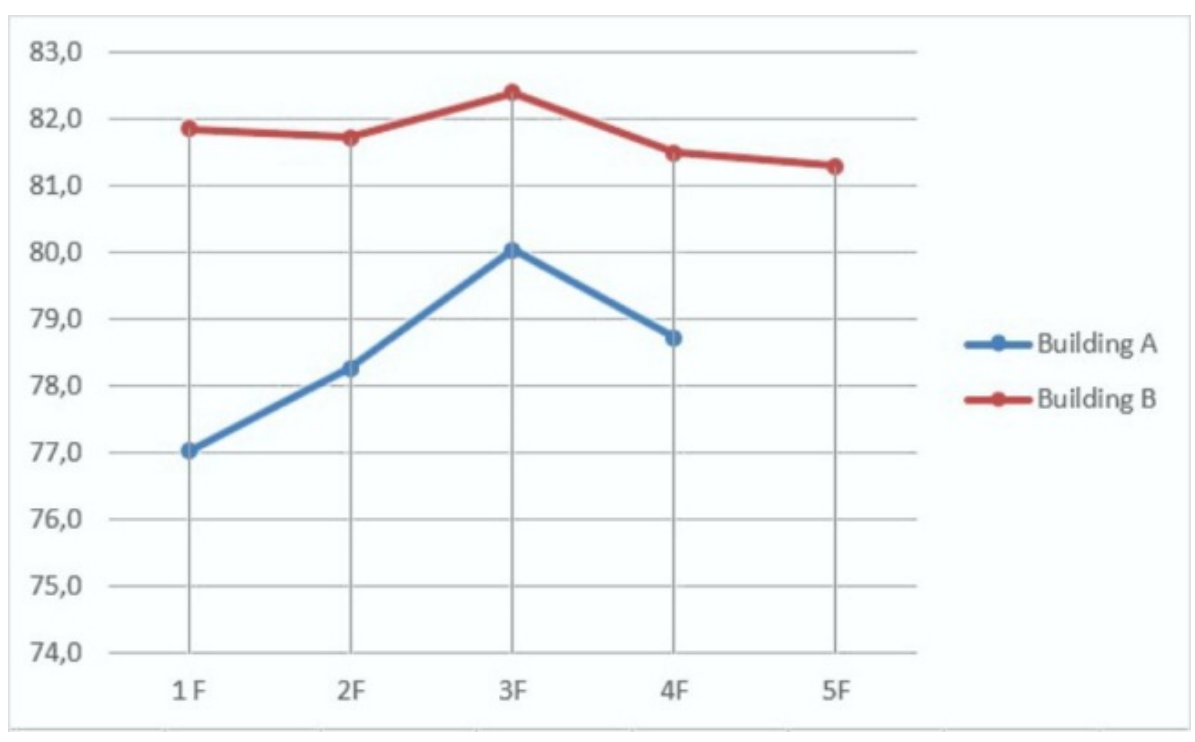

Figure 9. Daily Average Relative Humidity (\%) of Building A and B 


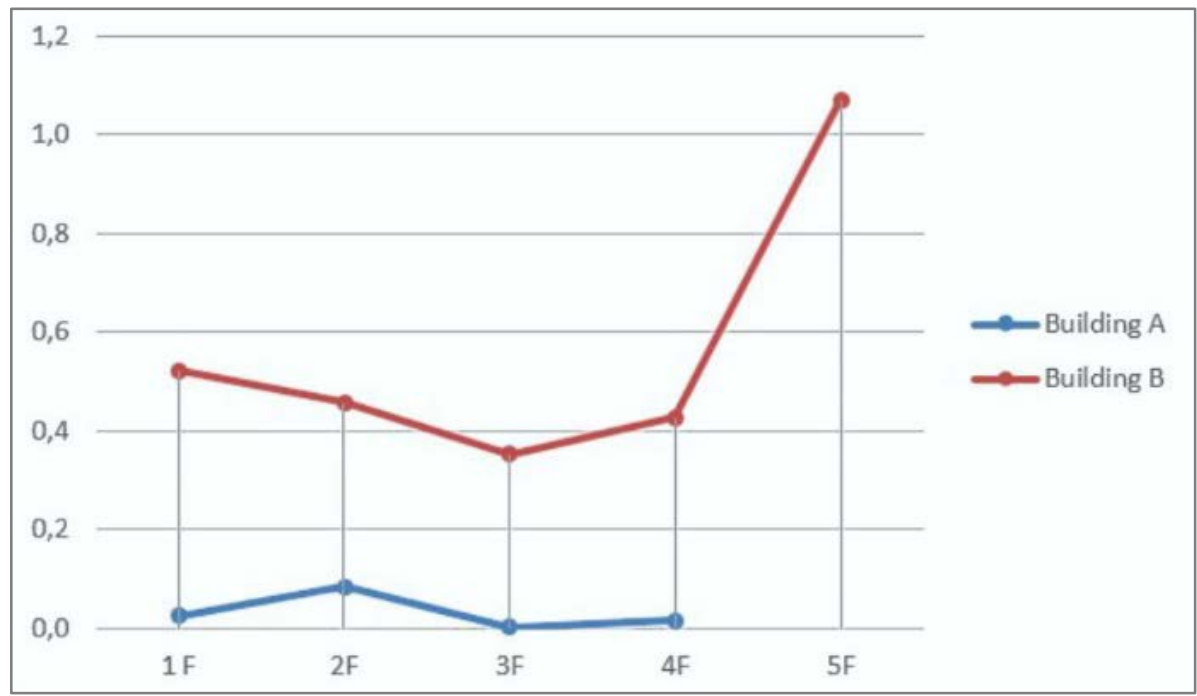

Figure 10. Daily Average Air Velocity $(\mathrm{m} / \mathrm{s})$ of Building A and B

Continuing Figure 10, the fifth floor of Building B performs excellent air circulation with an average wind speed of $1,1 \mathrm{~m} / \mathrm{s}$ (see Figure. 10). Each floor of Building $B$ has a wind speed value above $0.0 \mathrm{~m} / \mathrm{s}$. In other words, there is always wind movement recorded every day. The lowest average wind speed of Building B was nearly 0.4 $\mathrm{m} / \mathrm{s}$, which occurred on the third floor. On the contrary, the highest average wind speed value of Building B was experienced by the fifth floor with a value reaching 1.1 $\mathrm{m} / \mathrm{s}$. Based on ASHRAE 2017, the standard indoor air movement for thermal comfort is about $0.2 \mathrm{~m} / \mathrm{s}$ [16]. In other words, Building $\mathrm{B}$ has a better air circulation than Building A with a suitable standard, while Building A has a lack of air movement with the average value below standard, based on ASHRAE 2017. However, the wind depends on the natural daily weather conditions, so sometimes there is no air movement marked with $\mathrm{V}=0$ $\mathrm{m} / \mathrm{s}$.

The average daily $\mathrm{CO}_{2}(\mathrm{ppm})$ level in Building A and $\mathrm{B}$ can be found in Figure. 11. The lowest $\mathrm{CO}_{2}$ value close to $430 \mathrm{ppm}$ occurs on the first floor of Building B. In contrast, the highest $\mathrm{CO}_{2}$ value is on the second floor of Building A which reaches $604.9 \mathrm{ppm}$. In general, the daily level of carbon dioxide in Building A is about 500.3-604.9 $\mathrm{ppm}$. Meanwhile, the average daily value of carbon dioxide in Building B is distributed at about $443-454.4$ ppm on each floor. The $\mathrm{CO}_{2}$ level in dwellings considers reasonable value at $660 \mathrm{ppm}$ [18]. On the other side, the $\mathrm{CO}_{2}$ level is tolerated in non-industrial environments at $1000 \mathrm{ppm}$ [16]. Building A and B have $\mathrm{CO}_{2}$ levels within the safe threshold according to ASHRAE 2017 and Persily $[16,18]$. Still, according to the same source, high $\mathrm{CO}_{2}$ effects in shortness of breath if its level exceeds health standard.

Figure. 12 shows the daily average of PM $2.5\left(\mu \mathrm{g} / \mathrm{m}^{3}\right)$ in Building A and B during five days of measurement. The average PM $2.5\left(\mu \mathrm{g} / \mathrm{m}^{3}\right)$ value tends to be higher in Building B compared to Building A. The PM 2.5 score of Building A is about $16.9 \mu \mathrm{g} / \mathrm{m}^{3}$ and slightly decreases to $15.1 \mu \mathrm{g} / \mathrm{m}^{3}$. Meanwhile, the PM 2.5 level of Building B smoothly fluctuates about $23.9-25.8 \mu \mathrm{g} / \mathrm{m}^{3}$. The highest PM 2.5 was on the first floor of Building B $\left(25.8 \mu \mathrm{g} / \mathrm{m}^{3}\right)$. In contrast, the lowest value is shown on the fourth floor of Building A $\left(15.1 \mu \mathrm{g} / \mathrm{m}^{3}\right)$. According to ASHRAE 2017, PM 2.5 levels between $12-15 \mu \mathrm{g} / \mathrm{m}^{3}$ per year for three years are safe for health [16]. The average exposure threshold within 24 hours is $35 \mu \mathrm{g} / \mathrm{m}^{3}$ for no more than $98 \%$ over a three-year period [16]. The average PM 2.5 in Buildings $\mathrm{A}$ and $\mathrm{B}$ are above the annual average but still within the 24-hour threshold allowed under ASHRAE 2017. 


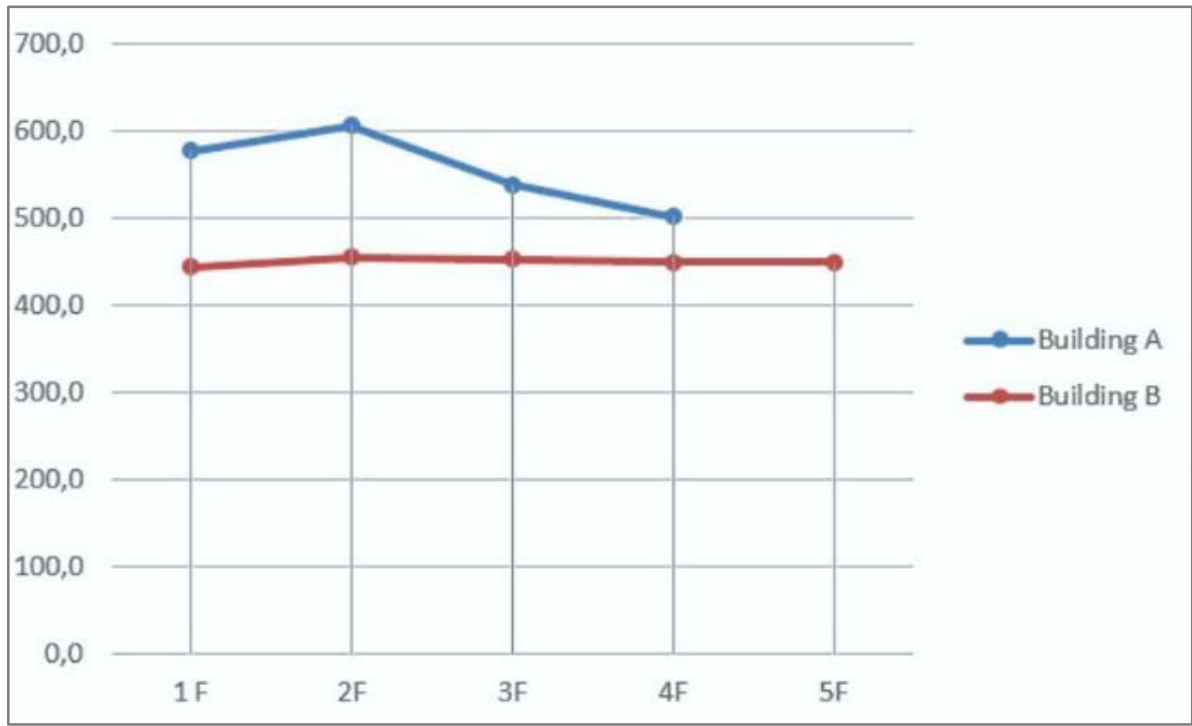

Figure 11. Daily Average Carbondioxide (ppm) of Building A and B

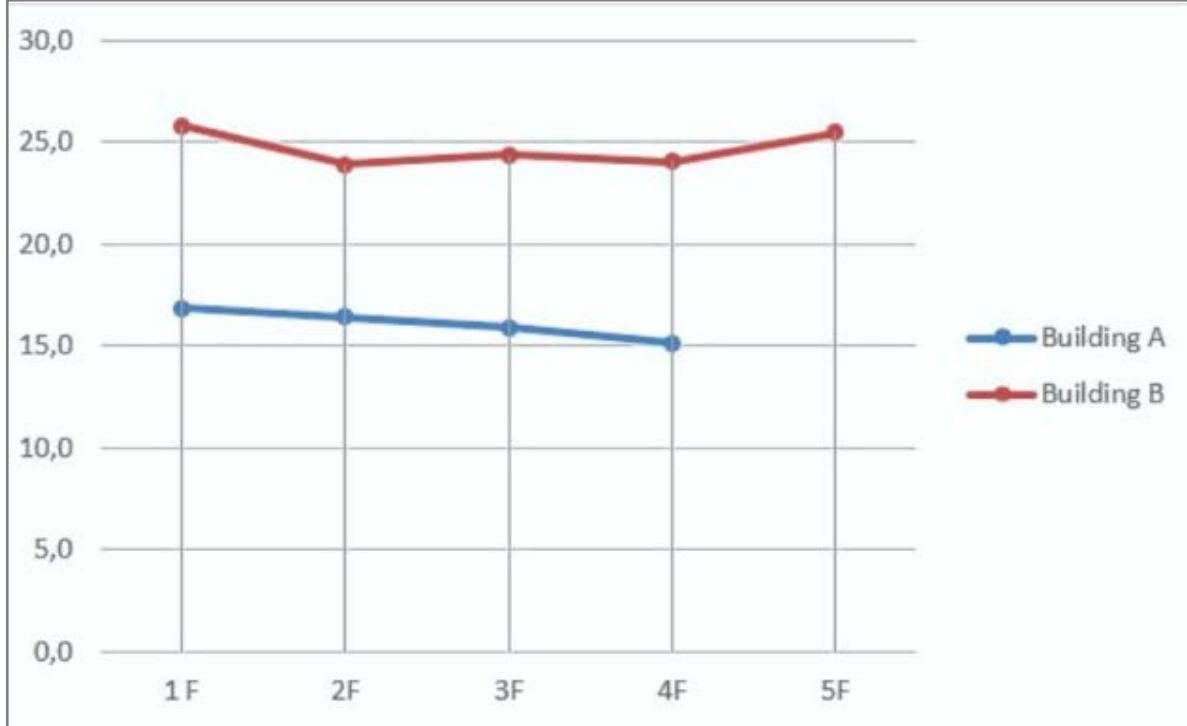

Figure 12. Daily Average PM $2.5\left(\mu \mathrm{g} / \mathrm{m}^{3}\right)$ of Building A and B 


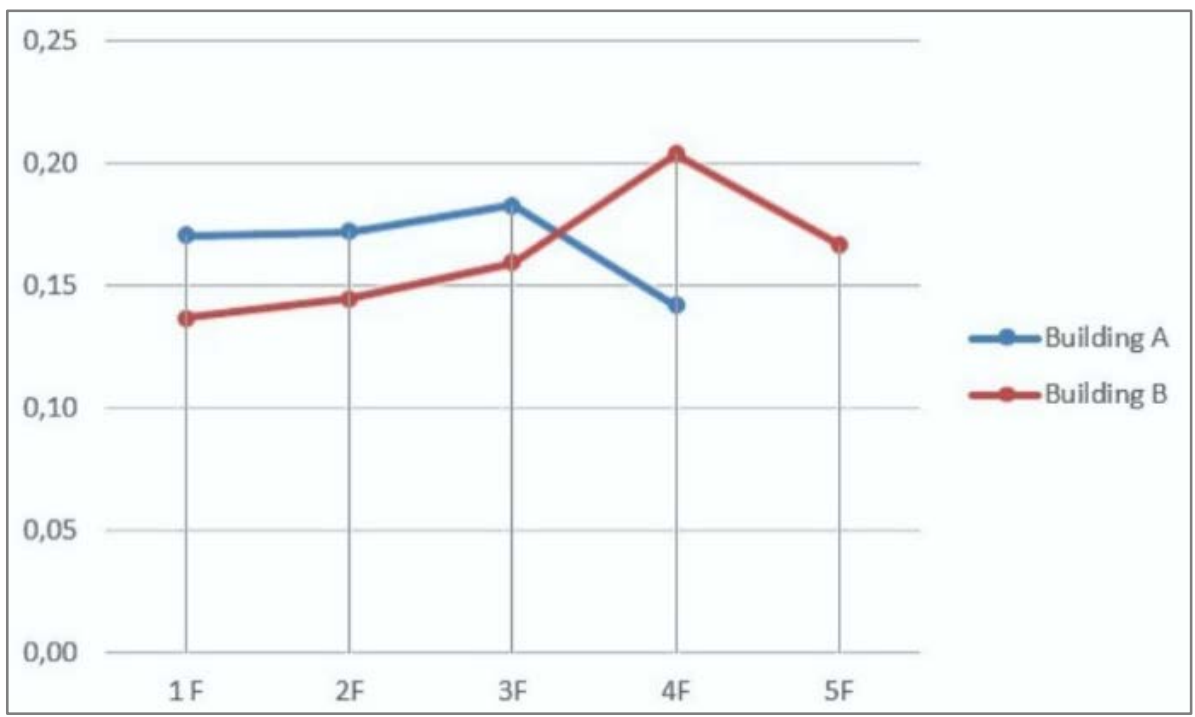

Figure 13. Daily Average TVOCs (ppm) in Building A and B

Figure. 13 shows the average daily TVOC (ppm) score in Building $\mathrm{A}$ and $\mathrm{B}$ in five days of measurement. In general, the TVOC content ranges from 0.14 to $0.20 \mathrm{ppm}$. The fourth floor of Building $\mathrm{B}$ experienced the highest TVOC value to close to $0.2 \mathrm{ppm}$. In contrast, the first floor of Building A had the lowest average score of all, which nearly reached 0,14 ppm. The highest level of VOC in Building A is 0.18 ppm. Common types of VOCs in the room include benzene [16] and formaldehyde [15]. Furthermore, according to the WHO, the presence of benzene should be as low as possible, and formaldehyde is no more than $0.081 \mathrm{ppm}$ in 30 minutes [16]. The total VOC levels in Building A and B are likely to exceed the standard stipulated by ASHRAE and WHO.

\subsection{Thermal Comfort and Indoor Air Quality Perception}

The questionnaires explored thermal comfort and indoor air quality perception. There were 44 occupants from Building $\mathrm{A}$, and 35 occupants from Building $\mathrm{B}$ responded to the questionnaires. The total numbers of respondents were 79 people. The data analysis of Model 1 and Model 2 used questionnaire outcome and described the occupant perception from Building A and B.

Table 1 shows the perception of Relative Humidity (RH) on a scale between 1-5. Scale 1-5 means 'damp' (1) to 'dry' (5) perception. The relative humidity in Building A was around $77 \%-78.7 \%$, perceptions of relative humidity in Building A largely declared 'neutral' or $56.8 \%$ of building A respondents. About 27.3\% of respondents said on a scale of 4 or 'slightly dry' in building A. Only $9 \%$ of respondents said it was 'slightly damp' and 4.5\% 'damp'. While in Building $B$, with humidity between 80.2\%-82.4\%, about $42.9 \%$ declared 'neutral' humidity, $40 \%$ was 'slightly dry', and only $8.6 \%$ said 'slightly damp' and 'dry' (8.6\%). Due to the air circulation in Building B was quite good, therefore, it can offset the high relative humidity. The relative humidity of both buildings was not in line with ASHRAE 2017 [16] and Permenkes RI no.1077/Menkes/Per/V/2011 [37,38]. Both of the sources state the ideal relative humidity is about $40-60 \%$ [16,37]. The perception result indicates some adaptive behaviors of the occupants to obtain the preference comfort. These adaptive behaviors lead to tolerance ability to the unstandardized humidity.

Table 1. Thermal Comfort and Indoor Air Quality Perception in Building A and B

\begin{tabular}{|c|c|c|c|c|c|c|}
\hline \multirow{3}{*}{ Building } & \multirow{2}{*}{ Parameter } & \multicolumn{5}{|c|}{ Perception Scale } \\
\cline { 2 - 7 } & & 1 & 2 & 3 & 4 & 5 \\
\hline \multirow{3}{*}{ A } & $\mathrm{T}$ & 0 & 2 & 18 & 19 & 5 \\
\cline { 2 - 7 } & $\mathrm{RH}$ & 2 & 4 & 25 & 12 & 1 \\
\cline { 2 - 7 } & $\mathrm{V}$ & 0 & 2 & 30 & 8 & 2 \\
\cline { 2 - 7 } & $\mathrm{QA}$ & 0 & 4 & 14 & 16 & 10 \\
\hline \multirow{3}{*}{ B } & $\mathrm{T}$ & 0 & 2 & 22 & 10 & 1 \\
\cline { 2 - 7 } & $\mathrm{RH}$ & 0 & 3 & 15 & 14 & 3 \\
\cline { 2 - 7 } & $\mathrm{V}$ & 1 & 1 & 13 & 13 & 7 \\
\cline { 2 - 7 } & QA & 0 & 6 & 14 & 10 & 5 \\
\hline
\end{tabular}

Table 1 presents the air circulation perception which is shown by a 1-5 scale describing stuffy (1) to windy (5) conditions. The majority of Building A inhabitants felt 'neutral' for air velocity perception, meanwhile, the airspeed was known under the standard value of ASHRAE 2017 [16]. Although the average wind speed of Building A only ranged from $0-0.1 \mathrm{~m} / \mathrm{s}$, the perception of the majority of residents was 'neutral' (68.2\%), 18.2\% 'slightly windy' and $4.5 \%$ 'windy'. According to ASHRAE, the indoor wind speed standard is approximately $0.2 \mathrm{~m} / \mathrm{s}$ [16], while the standard Indonesian 
Ministerial Decree no.1077/Menkes/Per/V/2011 [34,35] that is, about $0.15-0.25 \mathrm{~m} / \mathrm{s}[37,38]$. It means, there is an indication for some adaptive behaviors of the dwellers of Building A resulting to comfort tolerance. On the other side, most of Building B occupants had 'neutral' (37.1\%), 'slightly windy' (37.1\%), to 'windy' (20\%) perception. Generally, the average wind speed in Building $B$ is in line with ASHRAE 2017 standard, therefore, it can be understood that most of the residents vote 'neutral' to 'windy'.

The thermal perception of Building A and B compares to thermal measurement of the same location. The previous description of the temperature measurement shows the average temperature of both Building A and B does not meet ASHRAE 2017 thermal comfort standard [16]. As can be seen in Table 1., Building A performs an average temperature slightly higher than building $\mathrm{B}$, which is about $30-31.9^{\circ} \mathrm{C}$. Meanwhile, the temperature perception results in Building A showed $43.2 \%$ of respondents stated 'warm', $11.4 \%$ distinguished 'hot', the remaining $40.9 \%$ said 'neutral', and $4.5 \%$ 'cool mild'. In Building B, about $28.6 \%$ of respondents said the temperature was 'warm', only $2.9 \%$ expressed 'hot' or a scale of 5 , with a temperature range of $29.4-29.8^{\circ} \mathrm{C}$. Thermal perception in Building B was 'neutral' for about $62.9 \%$ of respondents, and $28.6 \%$ declared 'cool mild'. Meanwhile, the number of respondents who said 'warm' in both dormitories was $36.7 \%$, and 'neutral' $50.6 \%$. The perception indicates comfort tolerance of the occupants, due to their adaptive behavior to gain the expected comfort. The adaptive behaviors of the occupants are the activities such as rest and relaxation, and opening the windows in the commmon room. Generally, those are in line with natural adjustment to reduce discomfort and psychological strain [16]. Those activities indicate that adaptive behaviors can influence occupant's perception of indoor thermal comfort. The adaptive models can predict the preferable temperature to gain a comfortable temperature, due to the unsuitable result of temperature measurement according to ASHRAE 2017 [16].

The indoor air quality perceptions of residents in Building A and Building B are in Table 1. Table 1 shows the average $\mathrm{CO}_{2}$ level in Building $\mathrm{A}$ is between 503.3-604.9 ppm. Meanwhile, PM 2.5 of Building A is about $15.1-16.9 \mu \mathrm{g} / \mathrm{m}^{3}$ and TVOC around $0.14-0.18 \mathrm{ppm}$. With the conditions, $31.8 \%$ of respondents in Building A declared air quality 'neutral', and 9\% expressed 'slightly smelly' (scale 2), the remaining 36.4\% felt 'slightly fresh' air quality, and $22.7 \%$ 'fresh'. While in Building $\mathrm{B}$, the $\mathrm{CO}_{2}$ level is about $443-454.4 \mathrm{ppm}$, PM 2.5 is nearly 23.9-25.8 $\mu \mathrm{g} / \mathrm{m}$, and TVOC reaches $0.14-0.20 \mathrm{ppm}$. In these conditions, about $40 \%$ of respondents in Building B declared air quality 'neutral', 28.6\% stated 'slightly fresh' and $14.3 \%$ said 'fresh', of the rest, $11.4 \%$ stated 'slightly smelly'. As can be seen in Table 1., the air quality perception in Building A is better than Building $\mathrm{B}$. In the previous discussion, the relative humidity and PM 2.5 of Building $\mathrm{B}$ are higher than Building A. Both of these factors affect indoor air quality perception. PM 2.5 can be detected from smoke odor which indicates pollutant gas and dust from garbage combustion or engine emission [16].

In addition to harmful gases, indoor air can also be a means of spreading disease through fungal spores from the moist room, as well as bacteria and viruses from droplets or splashes of bodily fluids that are in the air $[16,20,21]$. The disease such as SARS can spread through the air [16]. Currently, as the Covid-19 is a type of coronavirus similar to SARS, the Covid-19 pandemic is considered as air contagious. By droplets, Covid-19 moves through the air and inhaled by healthy people around infected people [19]. The low ventilation levels are related to high infectious diseases among residents [16].

The presence of gases and air pollutants in space can not be detected in detail by the human senses. VOC type can give unpleasant odor as well as irritation reaction of the respiratory mucosal layer [16]. Therefore, in case of the perception of air quality, the terms 'smell' and 'air freshness' indicate the presence of gases or pollutants in indoor air. As the perception detects the air quality by the sense of air ambiance, the perception score is also including all the gas types. The mixed gas means a compound of some types of gas that can be indoor air pollutants such as TVOC (ppm) and $\mathrm{CO}_{2}(\mathrm{ppm})$. On the other side, particulate matter of PM $2.5\left(\mu \mathrm{g} / \mathrm{m}^{3}\right)$ is generally found in the outdoor space from vehicle emissions of the outdoor environment [4]. In case the particulate matter enters the room by the ventilation system, this research considers PM 2.5 as one of the factors of indoor air quality in conjunction with TVOC and $\mathrm{CO}_{2}$. The concept is in line with some references that explain the $\mathrm{CO}_{2}$, TVOC and PM 2.5 as the influential factors of indoor air quality [23-26].

\subsection{Indication Sick Building Syndrome}

Indication of sick building syndrome is calculated by the value of the SBS questionnaire's total scores of 68 points. Each respondent gets a score by dividing the maximum score, resulting in an SBS indication score. Category division stipulates by SBS score $<0.3$ as low SBS, SBS score $<0.3<0.6$ is moderate SBS, and more than 0.6 includes heavy SBS. The SBS score of Building A is 0.42 and Building $B$ is 0.39 , which means both buildings have a medium risk of SBS. The prevalence of sick building syndrome in Building A and Building B reaches $75 \%$ with $20 \%$ clinical accuracy, based on reference [33]. The prevalence of sick building syndrome in Building $\mathrm{A}$ is $73 \%$, and Building B is $77 \%$. The average comparison of sick building syndrome scores in Building A and Building B shows no significant average differences. 


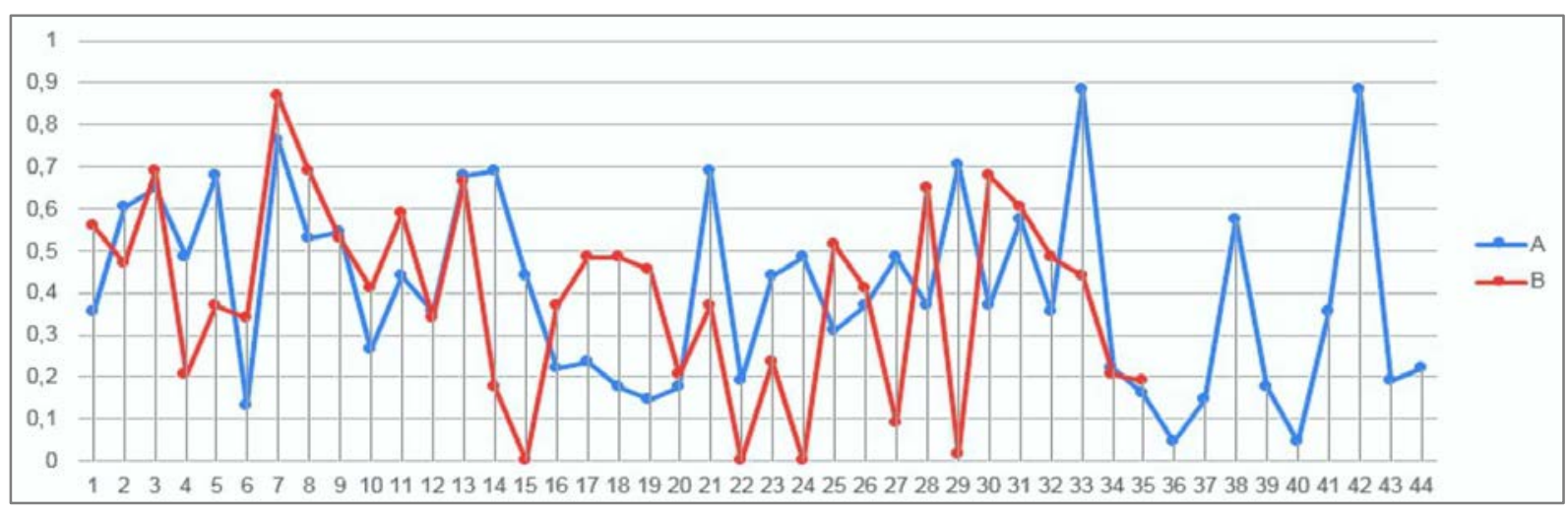

Figure 18. Sick Building Syndrome Indication in Building A and Building B

$S B S$ index $=-1.112+0.002 \mathrm{CO}_{2}+0.029 \mathrm{PM}-$ 1.109 TVOC

Indications of sick building syndrome (SBS) in Building A and B are in Figure.18. In Building A, SBS's average indication score is 0.42; meanwhile, in Building B, the SBS average score is 0.39 . The scores indicate moderate SBS level. Figure. 18 shows no residents who are free from SBS indications in Building A. About 36\% of Building A respondents indicate mild SBS, while $64 \%$ indicate SBS is moderate to heavy. On the other side, some respondents in Building B show 0 scores, which means some respondents are free from SBS. About 28.6\% of Building B respondents indicate mild SBS, $8.6 \%$ are asymptomatic of SBS, and the remaining $37.2 \%$ indicate moderate-heavy SBS. The SBS indication in Building B is smaller than Building A. Both Building A and Building B have medium-weight SBS presentations of more than $20 \%$. With more than 20\% SBS indication, a building can be called having the risk of sick building syndrome [37]. In other words, both Building A and Building B have the potential for sick building syndrome with no significant difference.

The regression formula of indoor air pollution effect on SBS index is presented as equation (1). The equation (1) means the SBS index has constant -1.112. For example, if the $\mathrm{CO}_{2}$ increases $1000 \mathrm{ppm}$, the SBS index will increase at least 0.888 regardless the PM 2.5 and TVOC value. In fact, there always be PM 2.5 and TVOC in both Building $\mathrm{A}$ and $\mathrm{B}$, and the $\mathrm{CO}_{2}$ is no more than $1000 \mathrm{ppm}$. The maximum score of the SBS index is 1, therefore, the equation is acceptable to calculate the SBS index. The SBS Index equation is a result of air pollutan and SBS regression. The formulation can be used to predict SBS Index in the next research. The effect of indoor air pollutant on sick building syndrome indication can be seen in the Table 3.

Table 2 shows air pollutant influence on the SBS index. The most significant value of the regression analysis is $\mathrm{CO}_{2}$ with a score of 0.037 . Meanwhile, other pollutants such as PM 2.5 and TVOC are not remarkable due to its significance values are more than 0.05 . In other words,
$\mathrm{CO}_{2}$ plays an important role in SBS risk in both Building $\mathrm{A}$ and $\mathrm{B}$ respectively. The result is in line with the research which stated $\mathrm{CO}_{2}$ as the most influential pollutant that worsens the SBS symptoms indoors [25]. Besides, the involvement of $\mathrm{CO}_{2}$ on SBS reveals as a compound of relative humidity aspects $[25,26]$, VOC, temperature [26] and PM 2.5.

Table 2. Air Pollutants Influence on SBS Index

\begin{tabular}{|c|c|c|c|c|c|c|}
\hline \multicolumn{7}{|c|}{ Coefficients $^{\mathrm{a}}$} \\
\hline \multirow{2}{*}{\multicolumn{2}{|c|}{ Model }} & \multicolumn{2}{|c|}{$\begin{array}{l}\text { Unstandardized } \\
\text { Coefficients }\end{array}$} & \multirow{2}{*}{$\begin{array}{c}\text { Standardized } \\
\text { Coefficients }\end{array}$} & \multirow[t]{2}{*}{$\mathrm{t}$} & \multirow[t]{2}{*}{ Sig. } \\
\hline & & B & Std. Error & & & \\
\hline \multirow{4}{*}{1} & (Constant) & -1.112 & .710 & & -1.567 & .121 \\
\hline & $\mathrm{CO} 2$ & .002 & .001 & .505 & 2.126 & .037 \\
\hline & PM & .029 & .016 & .518 & 1.883 & .064 \\
\hline & TVOC & -1.109 & .867 & -.227 & -1.279 & .205 \\
\hline
\end{tabular}

a. Dependent Variable: SBS Index

\subsection{Comparison of Analytical Model 1 and Model 2}

Analytical Model 1 uses independent variables of temperature, relative humidity, wind speed, and air quality resulting from field measurements. The dependent variable of this model is an indication of sick building syndrome (SBS). As in the previous section, the thermal comfort aspect [12,26] and indoor air quality [23-26] correlated to sick building syndrome incidents. Air quality variables are selected among others $\mathrm{CO}_{2}$, PM 2.5, and TVOC, based on the most frequently mentioned in various articles [23-26]. As in the previous discussion, only $\mathrm{CO}_{2}$ plays important role in SBS Index, among indoor air pollutant types. Meanwhile, in Model 1, the air pollutants are combined with the thermal comfort parameters, to know the effect of indoor air quality and thermal comfort on SBS risk. The following analyses find the most influential air pollutant type in Model 1 and the significance of Model 1.

Analytical Model 2 is an analysis with independent variable temperatures (1), humidity (2), and wind speed (3), and air quality (4). The dependent variables of this 
model are indications of sick building syndrome (SBS Index). The variables of Model 2 are variables 1, 2, and 3 as the result of perception surveys translated on a scale of $1-5$. Model 2 is analyzed by a classic assumption test to see if it is accepted as an analysis model or not [36]. Model 2 uses data perception as independent variables and SBS indication as a dependent variable. The influence level of the indoor pollutant type in Model 1 can be seen in Tables 3, 4, and 5. Furthermore, the comparison of both Model 1 and Model 2 can be seen as follows.

Table 3. Model 1 Analysis with TVOC

\begin{tabular}{|c|c|c|c|c|c|c|}
\hline \multicolumn{7}{|c|}{ ANOVA $^{\mathrm{a}}$} \\
\hline \multirow{2}{*}{ Model } & $\begin{array}{c}\text { Sum of } \\
\text { Squares }\end{array}$ & df & $\begin{array}{c}\text { Mean } \\
\text { Square }\end{array}$ & F & Sig. \\
\hline \multirow{3}{*}{1} & Regression & 0.137 & 4 & 0.34 & 0.679 & $0.609^{\mathrm{b}}$ \\
\cline { 2 - 8 } & Residual & 3.741 & 74 & 0.51 & & \\
\cline { 2 - 8 } & Total & 3.878 & 78 & & & \\
\hline
\end{tabular}

a. Dependent Variable: SBS

b. Predictors: (Constant), TVOC, VEA, RHA, TA

Table 4. Model 1 Analysis with PM 2.5

\begin{tabular}{|c|c|c|c|c|c|c|}
\hline \multicolumn{7}{|c|}{ ANOVA $^{\mathrm{a}}$} \\
\hline \multicolumn{2}{|c|}{ Model } & $\begin{array}{c}\text { Sum of } \\
\text { Squares }\end{array}$ & $\mathrm{df}$ & $\begin{array}{c}\text { Mean } \\
\text { Square }\end{array}$ & F & Sig. \\
\hline \multirow{4}{*}{1} & Regression & 0.142 & 4 & 0.035 & 0.702 & $0.593^{\mathrm{b}}$ \\
\cline { 2 - 8 } & Residual & 3.737 & 74 & 0.050 & & \\
\cline { 2 - 8 } & Total & 3.878 & 78 & & & \\
\hline
\end{tabular}

a. Dependent Variable: SBS

b. Predictors: (Constant), PM, RHA, VEA, TA

Table 5. Model 1 Analysis with $\mathrm{CO}_{2}$

\begin{tabular}{|c|c|c|c|c|c|c|}
\hline \multicolumn{7}{|c|}{ ANOVA $^{\mathrm{a}}$} \\
\hline \multicolumn{2}{|c|}{ Model } & $\begin{array}{c}\text { Sum of } \\
\text { Squares }\end{array}$ & df & $\begin{array}{c}\text { Mean } \\
\text { square }\end{array}$ & F & Sig. \\
\hline \multirow{4}{*}{1} & Regression & 0.151 & 4 & 0.038 & 0.747 & $0.563^{\mathrm{b}}$ \\
\cline { 2 - 8 } & Residual & 3.728 & 74 & 0.050 & & \\
\cline { 2 - 8 } & Total & 3.878 & 78 & & & \\
\hline
\end{tabular}

a. Dependent Variable: SBS

b. Predictors: (Constant), CO2, TA, VEA, RHA

Table 3 shows the significance of the influence of TVOC and thermal comfort on SBS is 0.609. The result indicates an insignificant influence as it is above 0.05 , due to the significant value is under 0.05 [36]. Similarly, Table 4 presents the influence of PM 2.5 and thermal comfort on SBS is 0.593 . The output is more than 0.05 which also shows a negligible effect on SBS because the trusty score is below 0.05 [36]. The impact of $\mathrm{CO}_{2}$ and thermal comfort on SBS can be seen in Table 5, with a value of 0.563 . The result is more than 0.05 , which means the model is not accurate [36]. Although the value is not remarkable, it is the best value compared to TVOC and PM 2.5. Thus, $\mathrm{CO}_{2}$ is considered the most influential parameter on indoor air quality. Even though $\mathrm{CO}_{2}$ seems to be the most influential, these three pollutants do not show any significant role in the risk of sick building syndrome (SBS), based on the regression of Model 1 .

Table 6 shows result analysis of Model 1 with cumulative indoor pollutants including $\mathrm{CO}_{2}$, PM 2.5 and TVOC in total score (QAsum). It can be seen that Model 1 is not notable due to its significance value is 0.559 . The output is more than 0.05 , which means the model is negligible [36]. Nevertheless, this model is the nearest to a considerable one. The regression of Model 1 with cumulative pollutant (QAsum) shows the most considerable result of all. The outcome is in line with some references that the compound of TVOC and PM 2.5 increase the risk of SBS [23] and also a combination of $\mathrm{CO}_{2}$ and TVOC lead to SBS incidents [26].On the other side, the result of Model 2 regression analysis is in Table 7 , which shows a significance value of 0.002 . It means, this Model 2 is remarkable and available at a later stage of research. The result interprets the analysis Model 2 as independent variables and a remarkable effect on SBS dependent variable.

Table 6. Model 1 Analysis with Cumulative Indoor Air Polutant

\begin{tabular}{|c|c|c|c|c|c|c|}
\hline \multicolumn{7}{|c|}{ ANOVA $^{\mathrm{a}}$} \\
\hline \multicolumn{2}{|c|}{ Model } & Sum of Squares & df & Mean Square & F & Sig. \\
\hline \multirow{4}{*}{1} & Regression & .152 & 4 & .038 & .753 & $.559^{\mathrm{b}}$ \\
\cline { 2 - 8 } & Residual & 3.727 & 74 & .050 & & \\
\cline { 2 - 8 } & Total & 3.878 & 78 & & & \\
\hline
\end{tabular}

a. Dependent Variable: SBS

b. Predictors: (Constant), QAsum, TA, VEA, RHA

Table 7. Regression Result of Model 2

\begin{tabular}{|c|c|c|c|c|c|c|}
\hline \multicolumn{7}{|c|}{ ANOVA $^{\mathrm{a}}$} \\
\hline \multicolumn{2}{|c|}{ Model } & $\begin{array}{c}\text { Sum of } \\
\text { Squares }\end{array}$ & $\mathrm{df}$ & $\begin{array}{c}\text { Mean } \\
\text { Square }\end{array}$ & F & Sig. \\
\hline \multirow{4}{*}{1} & Regression & 0.767 & 4 & 0.192 & 4.562 & $0.002^{\mathrm{b}}$ \\
\cline { 2 - 8 } & Residual & 3.111 & 74 & 0.042 & & \\
\cline { 2 - 8 } & Total & 3.878 & 78 & & & \\
\hline
\end{tabular}

a. Dependent Variable: SBS

b. Predictors: (Constant), QA, TA, RHA, VEA

The cumulative pollutant (QAsum) performs the most influence on SBS risk, meanwhile, $\mathrm{CO}_{2}$ is the most dominant to SBS risk individually. In addition, the type of air pollutant in the reality is mixed into ambiance air that our sensory are unable to distinguish the type exactly. Therefore, the compound of air pollutant (QAsum) is preferred to be used for Model 1. After selecting the type of air pollutant that is the most notable for Model 1, the next step is testing a classic assumption. The calculation of classic assumption uses SPSS 24 referring to the multivariate analysis method [36].

The normality test of Model 1 is presented in Table 8. The normality test by the Kolmogorov Smirnov method shows 0.093 , which is significant at 0.484 . The result value 0.484 is more than 0.05 , indicating the normally distributed residual data of Model 1 [36]. On the other 
side, Table 9. shows the Kolmogorov Smirnov test to know the normality distribution of the data in Model 2 [33]. The Kolmogorov Smirnov's normality test output is 0.093 , and a remarkable value of 0.494 . Due to the output is 0.494 more than 0.05 , therefore, the residual data of Model 2 is a normal distribution [36].

Table 8. Normality Test of Model 1

One-Sample Kolmogorov-Smirnov Test

\begin{tabular}{|c|c|c|c|}
\hline & & & Unstandardized Residual \\
\hline \multicolumn{3}{|c|}{$\mathrm{N}$} & 79 \\
\hline \multirow{2}{*}{$\begin{array}{c}\text { Normal } \\
\text { Parameters }\end{array}$} & \multicolumn{2}{|c|}{ Mean } & .000 \\
\hline & \multicolumn{2}{|c|}{ Std. Deviation } & 219 \\
\hline \multirow{3}{*}{$\begin{array}{l}\text { Most Extreme } \\
\text { Differences }\end{array}$} & \multicolumn{2}{|c|}{ Absolute } & .093 \\
\hline & \multicolumn{2}{|c|}{ Positive } & .093 \\
\hline & \multicolumn{2}{|c|}{ Negative } & -.045 \\
\hline \multicolumn{3}{|c|}{ Test Statistic } & .093 \\
\hline \multicolumn{3}{|c|}{ Asymp. Sig. (2-tailed) } & $.087^{\mathrm{c}}$ \\
\hline \multirow{3}{*}{$\begin{array}{c}\text { Monte Carlo } \\
\text { Sig. (2-tailed) }\end{array}$} & \multicolumn{2}{|c|}{ Sig. } & $.484^{\mathrm{d}}$ \\
\hline & \multirow{2}{*}{$\begin{array}{c}99 \% \\
\text { Confidence } \\
\text { Interval }\end{array}$} & Lower Bound & 471 \\
\hline & & Upper Bound & .497 \\
\hline
\end{tabular}

a. Test distribution is Normal.

b. Calculated from data.

c. Lilliefors Significance Correction.

d. Based on 10000 sampled tables with starting seed 2000000.

Table 9. Normality Test of Model 2

One-Sample Kolmogorov-Smirnov Test

\begin{tabular}{|c|c|c|c|}
\hline & & & $\begin{array}{c}\text { Unstandardized } \\
\text { Residual }\end{array}$ \\
\hline $\mathrm{N}$ & & & 79 \\
\hline \multirow{2}{*}{$\begin{array}{c}\text { Normal } \\
\text { Parameters }^{\mathrm{a}}{ }^{\mathrm{b}}\end{array}$} & Mean & & 0.000 \\
\hline & Std.Deviation & & 0.199 \\
\hline \multirow{3}{*}{$\begin{array}{l}\text { Most Extreme } \\
\text { Differences }\end{array}$} & Absolute & & 0.093 \\
\hline & Positive & & 0.093 \\
\hline & Negative & & -0.053 \\
\hline \multicolumn{2}{|c|}{ Test Statistic } & & 0.093 \\
\hline \multicolumn{2}{|c|}{ Asymp.Sig. (2-tailed) } & & $0.089^{c}$ \\
\hline \multirow{3}{*}{$\begin{array}{l}\text { Monte Carlo } \\
\text { Sig.(2-tailed) }\end{array}$} & Sig. & & $0.494^{\mathrm{d}}$ \\
\hline & \multirow{2}{*}{$\begin{array}{c}99 \% \\
\text { Confidence } \\
\text { Interval }\end{array}$} & $\begin{array}{l}\text { Lower } \\
\text { Bound }\end{array}$ & 0.349 \\
\hline & & $\begin{array}{l}\text { Upper } \\
\text { Bound }\end{array}$ & 0.639 \\
\hline
\end{tabular}

a. Test distribution is Normal

b. Calculated from data

c. Lilliefors Significance Correction d. Based on 79 sampled tables with starting seed 2000000

Table 10. shows a multicollinearity test of Model 1 . The independent variables result in correlation values below 95\%. It means, there is no obvious multicollinearity in Model 1 [36]. Meanwhile, Table 11 presents the coefficient correlation analysis output of Model 2. The coefficient correlation test is no more than 0.95 . In other words, there is no multicollinearity between independent variables in the regression of Model 2.

Table 10. Coefficient Correlation of Model 1

Coefficient Correlation

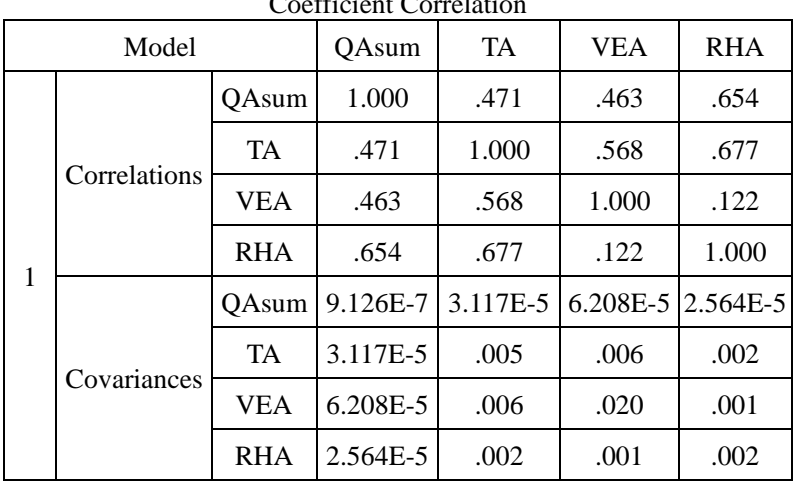

a. Dependent Variable: SBS

Table 11. Coefficient Correlation of Model 2 Coefficient Correlation

\begin{tabular}{|c|c|c|c|c|c|c|}
\hline \multicolumn{2}{|c|}{ Model } & & QA & TA & RHA & VEA \\
\hline \multirow{4}{*}{1} & \multirow{4}{*}{ Correlations } & QA & 1.000 & -0.187 & -0.247 & -0.316 \\
\cline { 3 - 7 } & & TA & -0.187 & 1.000 & -0.212 & 0.271 \\
\cline { 3 - 7 } & RHA & -0.247 & -0.212 & 1.000 & -0.404 \\
\cline { 3 - 7 } & & VEA & -0.316 & 0.271 & -0.404 & 1.000 \\
\cline { 3 - 7 } & QA & 0.001 & 0.000 & 0.000 & 0.000 \\
\cline { 3 - 7 } & TA & 0.000 & 0.001 & 0.000 & 0.000 \\
\cline { 3 - 7 } & RHA & 0.000 & 0.000 & 0.001 & 0.000 \\
\cline { 3 - 7 } & VEA & 0.000 & 0.000 & 0.000 & 0.001 \\
\hline
\end{tabular}

a. Dependent Variable: SBS

Table 12. shows the Variance of the Inflation Factor of Model 1. The Tolerance value is more than 0.1 , and the VIF value is no more than 10 . In other words, there is no multicollinearity among independent variables in Model 1 [36]. The result of the multicollinearity analysis of Model 2 can be found in Table 13, which shows a Tolerance of more than 0.1. The Variation Inflation Factor (VIF) value is no more than 10 . It means there is no correlation between independent variables whose value is more than $95 \%$ [36]. 
Table 12. Tolerance of Variance Inflation Factor of Model 1

\begin{tabular}{|c|c|c|c|c|c|c|c|c|}
\hline \multicolumn{9}{|c|}{ Coefficients $^{\mathrm{a}}$} \\
\hline & & \multicolumn{2}{|c|}{ Unstandardized Coefficients } & Standardized Coefficients & \multirow{2}{*}{$\mathrm{t}$} & \multirow{2}{*}{ Sig } & \multicolumn{2}{|c|}{ Collinearity Statistics } \\
\hline & Model & $\mathrm{B}$ & Std. Error & Beta & & & Tolerance & VIF \\
\hline \multirow{5}{*}{1} & (Constant) & 4.679 & 5.297 & .883 & .883 & .380 & & \\
\hline & TA & -.064 & .069 & -.922 & -.922 & .360 & .242 & 4.134 \\
\hline & RHA & -.033 & .041 & -.798 & -.798 & .428 & .206 & 4.852 \\
\hline & VEA & .043 & .141 & .307 & .307 & .759 & .326 & 3.064 \\
\hline & QAsum & .001 & .001 & .552 & .552 & .582 & .338 & 2.958 \\
\hline
\end{tabular}

a. Dependent Variable: SBS

Table 13. Tolerance and VIF of Model 2

Coefficients $^{\mathrm{a}}$

\begin{tabular}{|c|c|c|c|c|c|c|c|c|}
\hline & \multirow[b]{2}{*}{ Model } & \multicolumn{2}{|c|}{ Unstandardized Coefficients } & \multirow{2}{*}{$\begin{array}{c}\text { Standardized } \\
\text { Coefficients } \\
\text { Beta }\end{array}$} & \multirow[b]{2}{*}{$\mathrm{t}$} & \multirow[b]{2}{*}{ Sig. } & \multicolumn{2}{|c|}{ Collinearity Statistics } \\
\hline & & $\mathrm{B}$ & Std.Error & & & & Tolerance & VIF \\
\hline \multirow{5}{*}{2} & (Constant) & 0.516 & 0.157 & & 3.295 & 0.002 & & \\
\hline & TA & 0.080 & 0.035 & 0.255 & 2.302 & 0.024 & 0.884 & 1.131 \\
\hline & RHA & -0.107 & 0.036 & -0.386 & -3.005 & 0.004 & 0.657 & 1.521 \\
\hline & VEA & 0.036 & 0.033 & 0.143 & 1.101 & 0.275 & 0.646 & 1.549 \\
\hline & QA & -0.045 & 0.029 & -0.192 & -1.549 & 0.126 & 0.708 & 1.412 \\
\hline
\end{tabular}

a. Dependent Variable: SBS

Table 14. Heteroscedasticity Test of Model 1

Coefficients $^{\mathrm{a}}$

\begin{tabular}{|c|c|c|c|c|c|c|}
\hline & \multirow{2}{*}{ Model } & \multicolumn{2}{|c|}{ Unstandardized Coefficients } & \multirow{2}{*}{\begin{tabular}{|c|} 
Standardized Coefficients \\
Beta
\end{tabular}} & \multirow{2}{*}{$\mathrm{t}$} & \multirow{2}{*}{ Sig. } \\
\hline & & $\mathrm{B}$ & Std. Error & & & \\
\hline \multirow{5}{*}{1} & (Constant) & 8.548E-16 & 5.297 & & .000 & 1.000 \\
\hline & TA & .000 & .069 & .000 & .000 & 1.000 \\
\hline & RHA & .000 & .041 & .000 & .000 & 1.000 \\
\hline & VEA & .000 & .141 & .000 & .000 & 1.000 \\
\hline & QAsum & .000 & .001 & .000 & .000 & 1.000 \\
\hline
\end{tabular}

a. Dependent Variable: AbsUt

Table 15. Heteroscedasticity Test of Model 2

\begin{tabular}{|c|c|c|c|c|c|c|}
\hline \multicolumn{7}{|c|}{ Coefficients $^{\mathrm{a}}$} \\
\hline & \multirow{2}{*}{ Model } & \multicolumn{2}{|c|}{ Unstandardized Coefficients } & \multirow{2}{*}{$\begin{array}{c}\text { Standardized } \\
\text { Coefficients } \\
\text { Beta }\end{array}$} & \multirow[b]{2}{*}{$\mathrm{t}$} & \multirow[b]{2}{*}{ Sig. } \\
\hline & & B & Std.Error & & & \\
\hline \multirow{5}{*}{1} & (Constant) & 5.625E-16 & 5.222 & & 1.000 & 1.000 \\
\hline & TA & 0.000 & 0.068 & 0.000 & 0.000 & 1.000 \\
\hline & RHA & 0.000 & 0.041 & 0.000 & 0.000 & 1.000 \\
\hline & VEA & 0.000 & 0.142 & 0.000 & 0.000 & 1.000 \\
\hline & $\mathrm{CO}_{2}$ & 0.000 & 0.001 & 0.000 & 0.000 & 1.000 \\
\hline
\end{tabular}

a. Dependent Variable: AbsUt

The heteroscedasticity of Model 1 can be seen in Table 14 by analyzing the Glejser test. The output of the heteroscedasticity by Glejser test shows a level of significance of more than $5 \%$. Consequently, there are no independent variables that significantly affect dependent variables. In other words, there is neither heteroscedasticity nor autocorrelation in Model 1 [36]. Besides, the heteroscedasticity test of Model 2 is 
presented in Table.15. By the Gejser testing, the remarkable value is more than 0.05 , in other words, there is no heteroscedasticity in Model 2 [36].

Table 16. Run Test Result of Model 1

Run Test

\begin{tabular}{|c|c|}
\hline & Unstandardized Residual \\
\hline Test Value $^{\mathrm{a}}$ & -.008 \\
\hline Cases $<$ Test Value & 38 \\
\hline Cases $>=$ Test Value & 41 \\
\hline Total Cases & 79 \\
\hline Number of Runs & 37 \\
\hline Z & -.781 \\
\hline Asymp. Sig. (2-tailed) & .435 \\
\hline
\end{tabular}

a. Median

Table 17. Run Test Result of Model 2

Run Test

\begin{tabular}{|c|c|}
\hline & Unstandardized Residual \\
\hline Test Value $^{\mathrm{a}}$ & -0.017 \\
\hline Cases $<$ Test Value & 39 \\
\hline Cases $>=$ Test Value & 40 \\
\hline Total Cases & 79 \\
\hline Number of Runs & 36 \\
\hline Z & -1.018 \\
\hline Asymp.Sig. (2-tailed) & 0.309 \\
\hline
\end{tabular}

a. Median

Run Test Model 1 can be seen in Table 16. Run Test Model 1 indicates a significance of 0.435 or more than 0.05. This means, there is no autocorrelation in the variables in Model 1 [36]. In line with Table 14, Table 17 presents the Run test of Model 2. The Run Test of Model 2 shows a test value of -0.017 and a significance of 0.309 . Due to 0.309 is more than the significance of 0.05 , it can be said that there is no autocorrelation to residual values [36].

As the classic assumption test has been done, and the results are acceptable for Model 1, except for the regression test that shows the insignificant output of Model 1, therefore, it can be said that Model 1 is unsuitable to be used as an analytical model. Model 1 uses measurement data from thermal comfort and indoor air quality. The most dominant indoor air pollutant is $\mathrm{CO}_{2}$ individually, meanwhile, the compound of all $\mathrm{CO}_{2}$, TVOC, and PM 2.5 shows the most influential outcome of SBS risk. The resulting test of Model 1 indicates that there is another factor such as occupant's behavior affecting perception that can be increasing or ignoring SBS incidence.

Similar to Model 1, Model 2 applies the classic assumption test [36]. As it is described in the previous explanation of Model 1, Model 2 also uses the Kolmogorov Smirnov Test for normality test, followed by the multicollinearity test [36]. The Glesjer test identifies heteroscedasticity, meanwhile, Run Test analyzes the autocorrelation in Model 2 [36]. The classic assumption test of Model 2 shows an acceptable outcome for normality, autocorrelation, multicorrelation, and heteroscedasticity test. It means that Model 2 is a normal distribution, there is no autocorrelation, multicorrelation, and heteroscedasticity on Model 2. These results meet the requirement of an analytical model. In other words, Model 2 is rated more accurate than Model 1 to know the indications of sick building syndrome and can be accepted as an analysis model in subsequent research.

However, it does not mean those measurement aspects of thermal comfort and air quality are negligible. Due to the measurement results are within the comfort tolerance of the occupant, therefore, the outcome of the measurement does not significantly affect SBS's risk. In other words, there are possible aspects of the adaptive behavior of residents influence the indoor comfort and the risk of SBS. The occupant's behavior might increase or decrease the SBS index.

\section{Conclusions}

The average temperatures of both buildings are $29,4^{\circ} \mathrm{C}$ $-30,8^{\circ} \mathrm{C}$, according to ASHRAE 2017 standards, the temperature is beyond the comfort limit. However, about $50.6 \%$ of respondents showed neutrality, $36.8 \%$ stated 'quite hot', and $7.7 \%$ stated 'very hot'. The average relative humidity of both buildings is between $77 \%-82.4 \%$, the value is not in accordance with ASHRAE 2017 standards, but about $50.6 \%$ of respondents declared neutral, only $8.9 \%$ declared moist, and $2.5 \%$ very humid. This indicates the possibility of adaptation of occupants to temperature conditions and relative humidity in buildings.

Building A shows an average temperature slightly higher than building $\mathrm{B}$, which is about $30-30,8{ }^{\circ} \mathrm{C}$. The results of temperature perception in Building $\mathrm{A}$ showed $54.5 \%$ of House A respondents declared 'warm' or on a scale of $4-5$, the remaining $40.9 \%$ 'neutral', and $4.5 \%$ 'cool'. With temperature range $29,4-29,8^{\circ} \mathrm{C}$, about one-third of House B respondents said it was 'warm' or on a scale of 4-5. Thermal perception in Building B was 'neutral' for $42.9 \%$ respondents, and $5.7 \%$ expressed 'cool'. In other words, thermal comfort in Building B is better than Building $A$. The location of Building $A$ is in a low topographic urban area, while Building B is in a high green area. It reinforces the assertion that the location affects the thermal comfort of the resident. Wind speeds in Building A show an average range between 0-0.1 m/s, with a 'neutral' perception majority of $38 \%$ and $10 \%$ declared 'quite windy'. The 2017 ASHRAE standard requires a room wind speed of approximately $0.2 \mathrm{~m} / \mathrm{s}$. 
Thus, the perception of air movement in Building A indicates the occupant's adaptation to low air movement conditions and unstandardized indoor comfort.

A regression test is used to determine which $\mathrm{CO}_{2}, \mathrm{PM}$ 2.5 , or TVOC is the most influential on SBS. Test results show only $\mathrm{CO}_{2}$ has a remarkable effect on the SBS index. The regression equation of indoor air pollution influence on SBS index is shown in Eq. (1). Model 1 with independent variables $\mathrm{T}, \mathrm{RH}, \mathrm{V}$, and QA, which are the results of field measurements, as well as SBS dependent variable, cannot be said to be influential enough because the value of significance exceeds 0.05 . Model 2 with $\mathrm{T}$, $\mathrm{RH}, \mathrm{V}$, and QA variables that are the result of the perception scoring, as well as SBS dependent variables, can be said to have an effect with a significance value of 0.002 . Thus, model 2 is rated more accurately and acceptable as an analysis model. Continuing on Models 1 and 2 show thermal measurements and physical air quality do not influence SBS directly. On the contrary, perception has a significant role in SBS's risk. Therefore, the perception method in Model 2 considers more accurate than the measurement method in Model 1, as it contributes to the risk of SBS. The analysis of both Model 1 and Model 2 represent SBS risk is indirectly affected by thermal comfort and air quality measurement. Even though $\mathrm{CO}_{2}$ influences SBS Index remarkably, it becomes negligible in the Model 1 formula because of the possibility that the measurement results are still within the threshold of comfort tolerance and health standards. The aspect of indoor comfort tolerance relates to the adaptive behavior of the occupants, which it considers as strengthening or weakening the risk of SBS.

\section{Appendix}

\begin{tabular}{|l|l|}
\hline ASHRAE & $\begin{array}{l}\text { American Society of Heating, Refrigerating } \\
\text { and Air-Conditioning Engineers }\end{array}$ \\
\hline $\mathrm{CO}_{2}$ & Carbon dioxide in units of $\mathrm{ppm}$ \\
\hline PM 2.5 & Particle Matter 2,5 in units of $\mu \mathrm{g} / \mathrm{m}^{3}$ \\
\hline PMV & Predictive Mean Vote \\
\hline ppm & Part per million \\
\hline QA & Air Quality \\
\hline QA $_{\text {sum }}$ & $\begin{array}{l}\text { Total of air pollutant score consists of } \mathrm{CO}_{2}, \\
\text { TVOC and PM } 2.5\end{array}$ \\
\hline RH & Relative Humidity in units of $\%$ \\
\hline RHA & Average Relative Humidity in units of $\%$ \\
\hline SBS & Sick Building Syndrome \\
\hline T & Temperature in units of ${ }^{\circ} \mathrm{C}$ \\
\hline TA & Average Temperature in units of ${ }^{\circ} \mathrm{C}$ \\
\hline TVOC & $\begin{array}{l}\text { Total Volatile Organic Compound in units of } \\
\text { ppm }\end{array}$ \\
\hline V & Air velocity in units of m/s \\
\hline VEA & Average Air Velocity in units of $\mathrm{m} / \mathrm{s}$ \\
\hline VOC & Volatile Organic Compound in units of ppm \\
\hline
\end{tabular}

\section{Acknowledgement}

We would like to thank the Ministry of Education and Culture for receiving the Doctoral Dissertation. Thank you to the managers, respondents and participants from The University of Diponegoro Student Dormitory Association and the managers, respondents and participants of the Student Boarding School. KH Sahlan Rosjidi, Muhammadiyah University Semarang. Thank you for the surveyors that support the data collection at the research location.

\section{REFERENCES}

[1] [Sun, Y.; Zhang, Y.; Bao, L.; Fan, Z.; Wang, D.; Sundell, J. Effects of Gender and Dormitory Environment on Sick Building Syndrome Symptoms among College Students in Tianjin, China. Build. Environ. 2013, 68, 134-139, doi:10.1016/j.buildenv.2013.06.010.

[2] Stanaway, J.D.; Afshin, A.; Gakidou, E.; Lim, S.S.; Abate, D.; Abate, K.H.; Abbafati, C.; Abbasi, N.; Abbastabar, H.; Abd-Allah, F.; et al. Global, regional, and national comparative risk assessment of 84 behavioural, environmental and occupational, and metabolic risks or clusters of risks for 195 countries and territories, 1990-2017: A systematic analysis for the Global Burden of Disease Stu. Lancet 2018, 392, 1923-1994, doi:10.1016/S0140-6736(18)32225-6.

[3] Kobus, D.; Merenda, B.; Sówka, I.; Chlebowska-Styś, A.; Wroniszewska, A. Ambient air quality as a condition of effective healthcare therapy on the example of selected polish health resorts. Atmosphere (Basel). 2020, 11, doi:10.3390/ATMOS11080882.

[4] Seo, J.H.; Jeon, H.W.; Sohn, J.-R. Impact of the COVID-19 outbreak on air quality in Korea. Atmosphere (Basel). 2020.

[5] Matkovic, V.; Mulić, M.; Azabagić, S.; Jevtić, M. Premature adult mortality and years of life lost attributed to long-term exposure to ambient particulate matter pollution and potential for mitigating adverse health effects in Tuzla and Lukavac, Bosnia and Herzegovina. 2020, 1-12.

[6] Molina, F.Q.; Yaguana, D.B. Indoor Environmental Quality of Urban Residential Buildings in Cuenca-Ecuador: Comfort Standard. Buildings 2018, doi:10.3390/buildings8070090.

[7] Lu, C.; Deng, Q.; Li, Y.; Sundell, J.; Norbäck, D. Outdoor Air Pollution, Meteorological Conditions and Indoor Factors in Dwellings in Relation to Sick Building Syndrome (SBS) Among Adults in China. Sci. Total Environ. 2016, 560-561, 186-196, doi:10.1016/j.scitotenv.2016.04.033.

[8] Ulpiani, G.; Benedettelli, M.; Perna, C. di; Naticchia, B. Overheating Phenomena Induced by Fully-Glazed Facades: Investigation of a Sick Building in Italy and Assessment of the Benefits Achieved via Model Predictive Control of the AC System. Sol. Energy 2017, 158, 830-852, doi:10.1016/j.solener.2017.10.024.

[9] Çağlar, F.Z.; Gedik, G.Z.; Gökdemir, H. The impact of 
transparency ratio on thermal comfort: A field study on educational building. Civ. Eng. Archit. 2020, 8, 890-897, doi:10.13189/cea.2020.080516.

[10] Smedje, G.; Wang, J.; Norbäck, D.; Nilsson, H.; Engvall, K. SBS symptoms in relation to dampness and ventilation in inspected single-family houses in Sweden. Int. Arch. Occup. Environ. Health 2017, 90, 703-711, doi:10.1007/s00420-017-1233-z.

[11] Sun, C.; Zhang, J.; Guo, Y.; Fu, Q.; Liu, W.; Pan, J.; Huang, Y.; Zou, Z.; Huang, C. Outdoor Air Pollution in Relation to Sick Building Syndrome (SBS) Symptoms Among Residents in Shanghai, China. Energy Build. 2018, 174, 6876, doi:10.1016/j.enbuild.2018.06.005.

[12] Amin, N.D.M.; Akasah, Z.A.; Razzaly, W. Architectural Evaluation of Thermal Comfort: Sick building Syndrome Symptoms in Engineering Education Laboratories. Procedia - Soc. Behav. Sci. 2015, 204, 19-28, doi:10.1016/j.sbspro.2015.08.105.

[13] Hermawan; Prianto, E.; Setyowati, E.; Sunaryo The thermal condition and comfort temperature of traditional residential houses located in mountainous tropical areas: An adaptive field study approach. Int. J. Adv. Sci. Eng. Inf. Technol. 2019, 9, 1833-1840, doi:10.18517/ijaseit.9.6.3560.

[14] Setyowati, E.; Pribadi, S.B.; Aidon Uda, S.A.K.; Debby, T.R.; Harsritanto, B.I.R. The planning and design of kampong Pakuncen in Yogyakarta based on the green concept. J. Archit. Urban. 2019, 43, 21-35, doi:10.3846/jau.2019.6123.

[15] Norbäck, D.; Zhang, X.; Fan, Q.; Zhang, Z.; Zhang, Y.; Li, B.; Zhao, Z.; Huang, C.; Deng, Q.; Lu, C.; et al. Home environment and health: Domestic risk factors for rhinitis, throat symptoms and non-respiratory symptoms among adults across China. Sci. Total Environ. 2019, 681, 320-330, doi:10.1016/j.scitotenv.2019.05.084.

[16] ASHRAE Fundamentals ASHRAE Handbook 2017 Fundamentals SI; 2017; ISBN 6785392187.

[17] Persily, A. Indoor Carbon Dioxide Concentrations in Ventilation and Indoor Air Quality Standards. In Proceedings of the 36th AIVC Conference " Effective ventilation in high performance buildings”, Madrid, Spain, 23-24 September 2015.; 2015.

[18] Persily, A.; de Jonge, L. Carbon dioxide generation rates for building occupants. Indoor Air 2017, 27, 868-879, doi:10.1111/ina.12383.

[19] Morawska, L.; Tang, J.W.; Bahnfleth, W.; Bluyssen, P.M.; Boerstra, A.; Buonanno, G.; Cao, J.; Dancer, S.; Floto, A.; Franchimon, F.; et al. How can airborne transmission of COVID-19 indoors be minimised? Environ. Int. 2020, 142, doi:10.1016/j.envint.2020.105832.

[20] Sun, Y.; Wang, Z.; Zhang, Y.; Sundell, J. In China, students in crowded dormitories with a low ventilation rate have more common colds: Evidence for airborne transmission. PLoS One 2011, 6, doi:10.1371/journal.pone.0027140.

[21] Kishi, R.; Ketema, R.M.; Ait Bamai, Y.; Araki, A.; Kawai, T.; Tsuboi, T.; Saito, I.; Yoshioka, E.; Saito, T. Indoor environmental pollutants and their association with sick house syndrome among adults and children in elementary school. Build. Environ. 2018, 136, 293-301, doi:10.1016/j.buildenv.2018.03.056.

[22] Farooq, S.; Zubair, F.; Kamal, M.A. Evaluation of ventilation system efficiency with reference to ceiling height in warm-humid climate of pakistan. Civ. Eng. Archit. 2020, 8, 824-831, doi:10.13189/cea.2020.080509.

[23] Sun, Y.; Hou, J.; Cheng, R.; Sheng, Y.; Zhang, X.; Sundell, J. Indoor air quality, ventilation and their associations with sick building syndrome in Chinese homes. Energy Build. 2019, 197, 112-119, doi:10.1016/j.enbuild.2019.05.046.

[24] Shan, X.; Zhou, J.; Chang, V.W.; Yang, E. Comparing mixing and displacement ventilation in tutorial rooms: Students ' thermal comfort , sick building syndromes , and short-term performance. Build. Environ. 2016, 102, 128137, doi:10.1016/j.buildenv.2016.03.025.

[25] Salleh, N.M.; Kamaruzzaman, S.N.; Mahyuddin, N. Sick Building Symptomps among Children Pre-Schools in Malaysia: Association of Different Ventilation Strategies. $J$. Build. Perform. 2013, 4, 73-81.

[26] Lu, C.; Lin, J.; Chen, Y.; Chen, Y. Building-Related Symptoms among Office Employees Associated with Indoor Carbon Dioxide and Total Volatile Organic Compounds. Int. J. Environ. Res. Public Health 2015, 5833-5845, doi:10.3390/ijerph120605833.

[27] Pan, S.; Xiong, Y.; Han, Y.; Zhang, X.; Xia, L.; Wei, S.; Wu, J.; Han, M. A Study on Influential Factors of Occupant Window-Opening Behavior in an Office Building in China. Build. Environ. 2018, 133, 41-50, doi:10.1016/j.buildenv.2018.02.008.

[28] Soebarto, V.; Bennetts, H. Thermal Comfort and Occupant Responses During Summer in a Low to Middle Income Housing Development in South Australia. Build. Environ. 2014, 75, 19-29, doi:10.1016/j.buildenv.2014.01.013.

[29] Jiao, Y.; Yu, H.; Wang, T.; An, Y.; Yu, Y. Thermal Comfort and Adaptation of the Elderly in Free-Running Environments in Shanghai, China. Build. Environ. 2017, 118, 259-272, doi:10.1016/j.buildenv.2017.03.038.

[30] Creswell, J.W. Research Design: Qualitative, Quantitative and Mixed Methods Approaches; 4th ed.; Sage Publication.Inc: California, 2014;

[31] Groat, L.; Wang, D. Architectural Research Methods; 2nd ed.; John Wiley and Sons,Inc.: New Jersey, 2013; ISBN 9780470908556 .

[32] Curtis, E.A.; Drennan, J. Quantitative Health Research Issues and Methods; A.Curtis, E., Drennan, J., Et.al, Eds.; Open University Press: Berkshire, England, 2013; ISBN 9780335245734

[33] Sastroasmoro, S.; Sofyan, I. Dasar-dasar Metodologi Penelitian Klinis; Sagung Seto: Jakarta, 2014;

[34] Sugiyono Metode Penelitian Kuantitatif, Kualitatif, dan R\&D; Alfabeta: Bandung, 2019; ISBN 6103544947.

[35] Dawe, M.; Raftery, P.; Woolley, J.; Schiavon, S.; Bauman, F. Comparison of mean radiant and air temperatures in mechanically-conditioned commercial buildings from over 200000 field and laboratory measurements. Energy Build. 2020.

[36] Ghozali, I. Aplikasi Analisis Multivariate dengan Program 
IBM SPSS; Badan Penerbit Universitas Diponegoro: Semarang, 2018;

[37] Mukono, H. Pencemaran Udara dalam Ruangan, Berorientasi Kesehatan Masyarakat; Airlangga University
Press: Surabaya, 2014;

[38] Menteri Kesehatan Republik Indonesia Pedoman Penyehatan Udara dalam Ruang Rumah. In Permenkes No.1077/Menkes/PER/V/2011; 2011. 